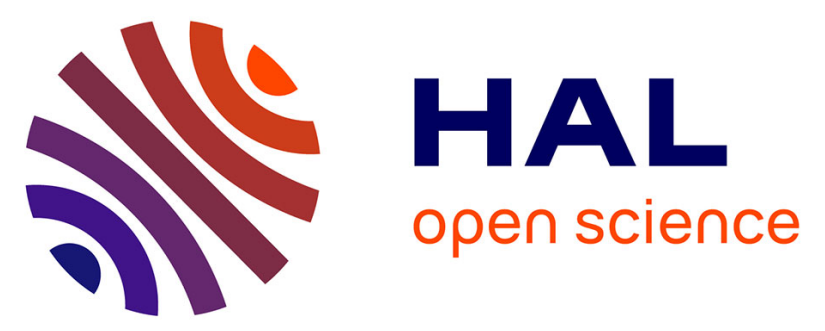

\title{
Surface, core, and structure modifications of phosphorus-containing dendrimers. Influence on the thermal stability
}

Cédric-Olivier Turrin, Valérie Maraval, Julien Leclaire, Eric Dantras, Colette Lacabanne, Anne-Marie Caminade, Jean Pierre Majoral

\section{To cite this version:}

Cédric-Olivier Turrin, Valérie Maraval, Julien Leclaire, Eric Dantras, Colette Lacabanne, et al.. Surface, core, and structure modifications of phosphorus-containing dendrimers. Influence on the thermal stability. Tetrahedron, 2003, vol. 59 (n 22), pp. 3965-3973. 10.1016/S0040-4020(03)00465-4 . hal01308062

\section{HAL Id: hal-01308062 https://hal.science/hal-01308062}

Submitted on 27 Apr 2016

HAL is a multi-disciplinary open access archive for the deposit and dissemination of scientific research documents, whether they are published or not. The documents may come from teaching and research institutions in France or abroad, or from public or private research centers.
L'archive ouverte pluridisciplinaire HAL, est destinée au dépôt et à la diffusion de documents scientifiques de niveau recherche, publiés ou non, émanant des établissements d'enseignement et de recherche français ou étrangers, des laboratoires publics ou privés. 


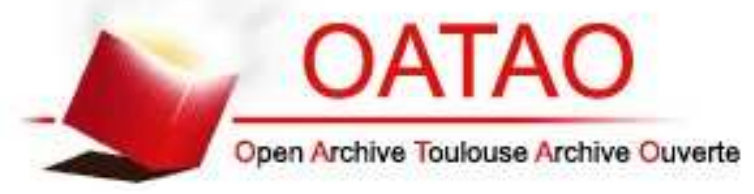

\section{Open Archive TOULOUSE Archive Ouverte (OATAO)}

OATAO is an open access repository that collects the work of Toulouse researchers and makes it freely available over the web where possible.

This is an author-deposited version published in : http://oatao.univ-toulouse.fr/ Eprints ID : 14316

To link to this article : DOI : 10.1016/S0040-4020(03)00465-4

URL : http://dx.doi.org/10.1016/S0040-4020(03)00465-4

To cite this version : Turrin, Cédric-Olivier and Maraval, Valérie and Leclaire, Julien and Dantras, Eric and Lacabanne, Colette and

Caminade, Anne-Marie and Majoral, Jean-Pierre Surface, core, and structure modifications of phosphorus-containing dendrimers. Influence on the thermal stability. (2003) Tetrahedron, vol. 59 ( $\left.\mathrm{n}^{\circ} 22\right)$. pp. 3965-3973. ISSN 0040-4020

Any correspondance concerning this service should be sent to the repository administrator: staff-oatao@ listes-diff.inp-toulouse.fr 


\title{
Surface, core, and structure modifications of phosphorus- containing dendrimers. Influence on the thermal stability
}

\author{
Cédric-Olivier Turrin, ${ }^{\mathrm{a}}$ Valérie Maraval, ${ }^{\mathrm{a}}$ Julien Leclaire, ${ }^{\mathrm{a}}$ Eric Dantras, ${ }^{\mathrm{b}}$ Colette Lacabanne, ${ }^{\mathrm{b}}$ \\ Anne-Marie Caminade ${ }^{a, *}$ and Jean-Pierre Majoral ${ }^{a, *}$ \\ ${ }^{a}$ Laboratoire de Chimie de Coordination CNRS, 205, route de Narbonne, 31077 Toulouse Cedex 4, France \\ ${ }^{\mathrm{b}}$ Laboratoire de Physique des Polymères, CIRIMAT, Université Paul Sabatier, 31062 Toulouse Cedex 4, France
}

\begin{abstract}
Three new series of phosphorus-containing dendrimers are described. Their solubility depends on the type of end groups they bear. Perfluoroalkyl chains give dendrimers soluble in chlorofluorocarbons, whereas guanidinium and pyridinium derivatives give watersoluble compounds. The thermal stability of these compounds, as well as of 19 other dendrimers of various generations, having various cores, or various end groups, or branching points is studied. The main feature of this study is that the internal structure of these dendrimers is thermally stable at least up to $376^{\circ} \mathrm{C}$. The number of the generation has practically no influence, whereas the principal criterion influencing the thermal stability is the type of end groups. The water-soluble cationic dendrimers are the least stable, but even those are stable up to $225^{\circ} \mathrm{C}$. For most of these dendrimers, an important percentage of mass (around 50\%) is retained even at a temperature as high as $1000^{\circ} \mathrm{C}$. In the best case, up to $70 \%$ of the initial mass is retained at $1000^{\circ} \mathrm{C}$.
\end{abstract}

\section{Introduction}

Dendrimers ${ }^{1}$ have attracted a tremendous interest for more than 15 years. The initial studies concerned the synthetic aspects, but efforts are now mainly directed toward applications. $^{2}$ In this perspective, the thermal stability appears as a crucial point for most applications of dendrimers, and particularly in the field of materials science. Even though a few papers previously described the thermal behaviour of PAMAM dendrimers, ${ }^{3}$ carbosilane dendrimers, ${ }^{4}$ or polyphenylene dendrimers, ${ }^{5}$ no study has been dedicated to the influence of the number of generations, the nature of the end groups, the core, and the branching points on the thermal stability of dendrimers. Thus, we decided to carry out this study using one of the most easily tunable family of dendrimers, that is the phosphorus-containing dendrimers that we have developed since $1994 .{ }^{6}$ Indeed, besides surface modifications, ${ }^{7}$ which are commonly used for almost all types of dendrimers, we have also demonstrated the possibility of modifying the type of core, ${ }^{8}$ the type of branching points, ${ }^{9}$ and the type of skeleton, ${ }^{10}$ even after the synthesis of the dendrimer ${ }^{11}$ (Fig. $1)$. This unique behavior is due to the presence of phosphorus as a component of the backbone of these dendrimers. ${ }^{12}$ This element brings ease of synthesis, helps with characterization, ${ }^{6}$ and gives properties seldom or never

\footnotetext{
Keywords: dendrimers; perfluoroalkyl chains; chlorofluorocarbons.

* Corresponding authors. Tel.: +33-561-333-123; fax: +33-561-553-003; e-mail: majoral@1cc-toulouse.fr, caminade@1cc-toulouse.fr.
}

found for other dendrimers, such as high dipole moment values, ${ }^{13}$ or formation of hydrogels ${ }^{14}$ and vesicles ${ }^{15}$ in water. Since it is well-known that phosphorus-nitrogen linkages impart an interesting thermal stability to polymers such as polyphosphazenes, ${ }^{16}$ an increased stability of our dendrimers (which possess $\mathrm{P}-\mathrm{N}-\mathrm{N}$ linkages), compared to

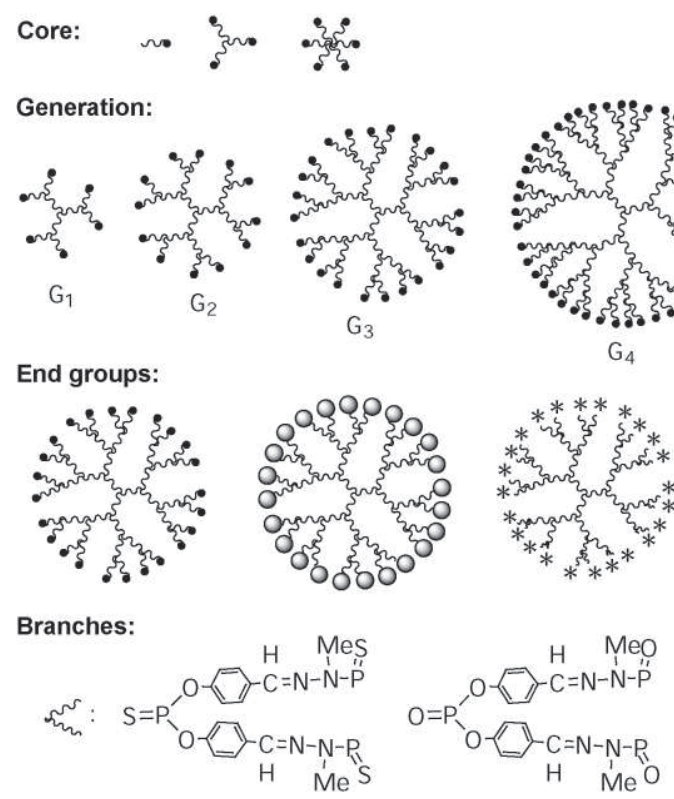

Figure 1. Schematized types of cores, generations, end groups and chemical structure of branches of dendrimers used in this study. For some examples concerning the type of end groups, see Figure 2. 


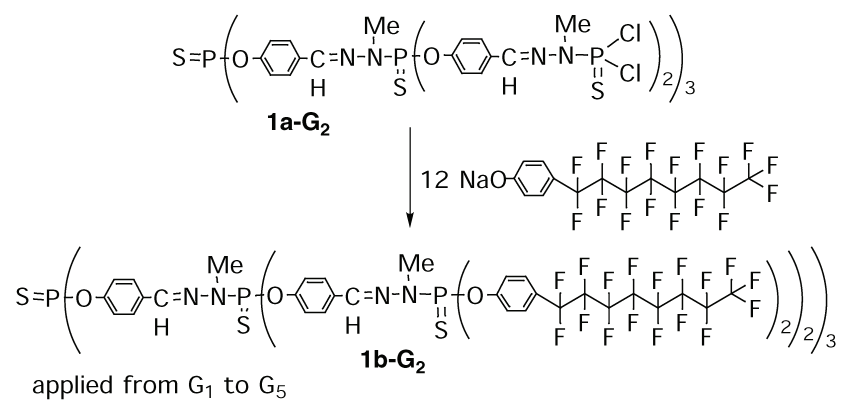

Scheme 1.

other types of dendrimers could be expected. On the other hand, we have shown that the $\mathrm{N}-\mathrm{N}=\mathrm{C}$ linkages also included in the branches of our dendrimers have a somewhat destabilizing effect, since they are sensitive to UV laser irradiation. ${ }^{17}$ To know which influence is the most important for the thermal stability, we decided to carry out a large study. First, we have synthesized dendrimers bearing new types of end groups, then we have studied their thermal behavior, together with that of a variety of previously reported dendrimers.

\section{Results and discussion}

Most of the dendrimers we have described previously are soluble in organic solvents such as THF, dioxane, dichloromethane, or chloroform. However, we have already demonstrated that the grafting of long alkyl chains induces solubility in alkanes, ${ }^{71}$ whereas the grafting of diethylammonium, ${ }^{18}$ trimethylammonium ${ }^{14}$ or carboxylic acid ${ }^{10 \mathrm{~d}, 15,19}$ end groups induces solubility in water. In order to vary the type of solvents usable for our dendrimers, we tried to obtain compounds soluble in chlorofluorocarbons (CFC). On the other hand, in view of the increasing importance of water-soluble dendrimers for biological uses, particularly those having positively charged end groups, there is a need for new compounds of this type. The following paragraph will show the synthesis of three new families of dendrimers related to these topics. Then, they are included in the general study concerning the thermal stability.

\subsection{Syntheses and solubility}

The way that appeared the easiest to obtain dendrimers soluble in CFC consists in the grafting of phenols bearing a long perfluoroalkyl chain. The phenol we chose was 4perfluorooctane phenol, obtained by the coupling reaction of iodoperfluorooctane and 4-iodophenol with copper. ${ }^{20}$ Its sodium salt easily reacts overnight at room temperature with the $\mathrm{P}(\mathrm{S}) \mathrm{Cl}_{2}$ end groups of dendrimers $\mathbf{1 b}-\mathbf{G}_{\mathbf{x}}$ in THF for small generation $(\mathbf{x}=1-2)$ or in $\mathrm{THF} / \mathrm{CFC} 113\left(\mathrm{ClF}_{2}\right.$ $\left.\mathrm{CCFCl}_{2}\right)$ for larger generations $(\mathbf{x}=3-5)$. The reaction is shown on Scheme 1 for the second generation of the dendrimer, but it was also carried out with all generations from $\mathbf{x}=1$ to $\mathbf{x}=5$ (6-96 perfluorooctane end groups). Beside singlets corresponding to the internal layers, ${ }^{31} \mathrm{P}$ NMR spectra of $\mathbf{1 b}-\mathbf{G}_{\mathbf{x}}$ indicate in all cases the presence of one singlet for the phosphorus atoms of the external layer, slightly shielded compared to $\mathbf{1} \mathbf{b}-\mathbf{G}_{\mathbf{x}}$. The solubility of these compounds depends on the generation: the first generation is soluble in $\mathrm{CHCl}_{3}$, but generations 2-5 are not. However, they are soluble in $\mathrm{CFC}$ as expected, and also in mixtures $\mathrm{CFC} / \mathrm{CHCl}_{3}(1 / 1)$.

We chose another way of grafting functional groups on the surface of dendrimers to obtain water-soluble compounds. In this case, the starting material was the dendrimer $\mathbf{2} \mathbf{c}-\mathbf{G}_{\mathbf{3}}$ having 48 aldehyde end groups and a cyclotriphosphazene core. A condensation reaction was carried out with aminoguanidine hydrochloride at $60^{\circ} \mathrm{C}$ in $\mathrm{THF} / \mathrm{MeOH}$, leading to the grafting of the guanidinium end groups (Scheme 2). The completion of the reaction was shown both by ${ }^{1} \mathrm{H}$ NMR and IR, with the total disappearance of signals corresponding to the aldehyde end groups. Dendrimer 2d$\mathbf{G}_{3}$ is soluble in water as expected, but a few drops of an organic solvent were needed to obtain clear NMR spectra. In the absence of organic solvent, the signals corresponding to the internal hydrophobic layers are not detected.

The same type of condensation reaction was carried out in THF at $40^{\circ} \mathrm{C}$ between 2-hydrazinopyridine and the second or third generation of dendrimers $\mathbf{2} \mathbf{c}-\mathbf{G}_{\mathbf{x}}(\mathbf{x}=2,3)$ (Scheme $3)$. The reaction occurred easily and was monitored as previously by ${ }^{1} \mathrm{H}$ NMR and IR, with the total disappearance of the signals corresponding to the aldehydes. The neutral dendrimers $\mathbf{2 e}-\mathbf{G}_{\mathbf{x}}$ are soluble in organic solvents, but not in water. However, a dramatic change in the solubility is observed when $\mathrm{HCl}$ (in water) is added. The protonation of the pyridine easily affords the dendrimer $\mathbf{2} \mathbf{f}-\mathbf{G}_{\mathbf{3}}$, which is soluble in water and also in DMSO. Beside modifications of the solubility, the protonation also induces a deshielding of most of the signals corresponding to the pyridine part in the ${ }^{1} \mathrm{H}$ and ${ }^{13} \mathrm{C}$ NMR spectra.

\subsection{Thermal stability}

In order to determine all the criteria influencing the thermal stability of phosphorus-containing dendrimers, we studied the behaviour of 24 dendrimers, including representative examples of the three families described above (Table 1).

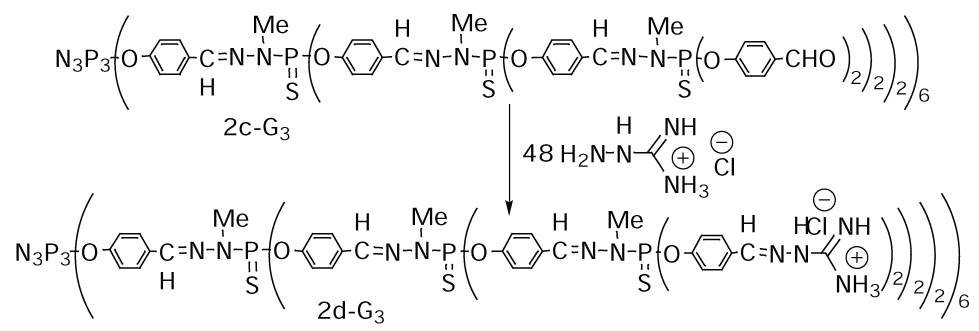

Scheme 2. 


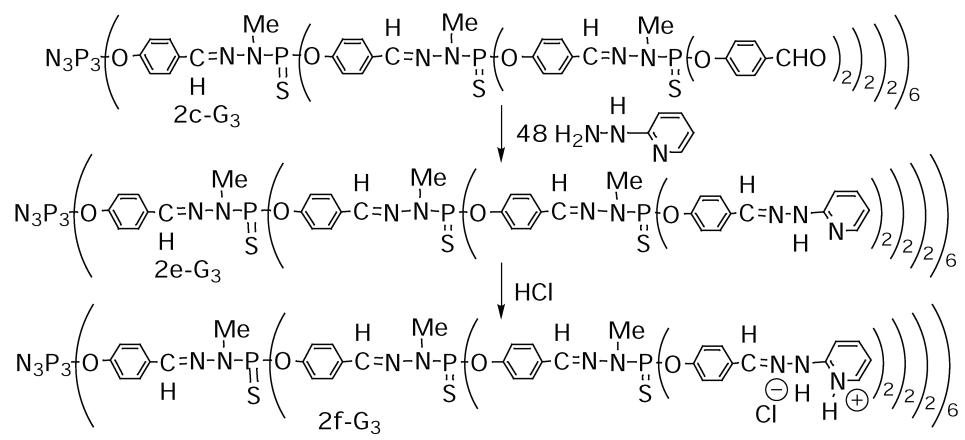

Scheme 3.

This exhaustive study was carried out with the aim of determining the importance of the generation (comparison from $\mathbf{1 c}-\mathbf{G}_{\mathbf{0}}$ to $\mathbf{1} \mathbf{c}-\mathbf{G}_{\mathbf{5}}$ ), of the internal structure (comparison $\mathbf{1 c}-\mathbf{G}_{\mathbf{3}} / \mathbf{3 c}-\mathbf{G}_{\mathbf{3}}$ ), of the core (comparison between $\mathbf{1 c}-\mathbf{G}_{\mathbf{x}}, \mathbf{2 c}-$ $\mathbf{G}_{\mathbf{x}}$, and $\mathbf{4} \mathbf{c}-\mathbf{G}_{\mathbf{x}}$ ), and of the end groups (from $\mathbf{a}$ to $\mathbf{n}$ ) (Fig. 2). Compounds possessing aldehyde end groups (series c) serve as a reference in all cases. Indeed, these end groups are the most easily available, since they are obtained at each generation during the synthesis of all our phosphoruscontaining dendrimers. Furthermore, we have already used these aldehyde-dendrimers for studying some physical properties using thermostimulated currents and broadband dielectric spectroscopy, ${ }^{21 \mathrm{a}, \mathrm{b}}$ and enthalpy relaxation. ${ }^{21 \mathrm{c}}$

Since some samples may contain 1-2\% of solvent (detected by ${ }^{1} \mathrm{H}$ NMR), we considered the temperature to which a loss of $5 \%$ in weight is observed as an indication of the beginning of the degradation (noted $T_{95 \%}$ in Table 1). Figure 3 displays the influence of the generation on the thermal stability from $\mathbf{1} \mathbf{c}-\mathbf{G}_{\mathbf{0}}$ to $\mathbf{1} \mathbf{c}-\mathbf{G}_{\mathbf{5}}$ under an inert gas. It appears from these graphs that the least stable compound is $\mathbf{1} \mathbf{c}-\mathbf{G}_{\mathbf{0}}$, but all dendrimers from $\mathbf{1 c}-\mathbf{G}_{\mathbf{1}}$ to $\mathbf{1 c}-\mathbf{G}_{\mathbf{5}}$ have roughly the same thermal behaviour. They are stable (less than 5\% loss) up to $300-330^{\circ} \mathrm{C}$. These phosphorus-containing dendrimers having aldehyde end groups are much more stable than PAMAM dendrimers $\left(5 \% \text { loss around } 110^{\circ} \mathrm{C}\right)^{3}$ and carbosilane dendrimers $\left(5 \%\right.$ loss between 100 and $200^{\circ} \mathrm{C}$, depending on the structure) ${ }^{4}$ but less stable than polyphenylene dendrimers $\left(5 \%\right.$ loss around $\left.500^{\circ} \mathrm{C}\right) .^{5}$ The shape of the decomposition curve indicates a first loss (of approximately $15 \%$ ) around $350^{\circ} \mathrm{C}$, followed by a plateau up to $\sim 450^{\circ} \mathrm{C}$. Then a second loss of $15-20 \%$ was observed, followed by a plateau up to $850-900^{\circ} \mathrm{C}$, irrespective of the generation. The percentage of mass retained at $1000^{\circ} \mathrm{C}$ is close to $50 \%$, which is a very high value.

This fact incited us to check the thermal behaviour of these

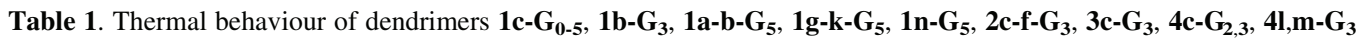

\begin{tabular}{|c|c|c|c|c|c|c|c|c|c|}
\hline Compound & Number of $\mathrm{R}$ & MW & $-\mathrm{Ar}^{\mathrm{a}} \%^{\mathrm{a}}$ & $\mathrm{C} \%^{\mathrm{b}}$ & $\mathrm{T}_{95 \%}{ }^{\mathrm{c}}$ & $\mathrm{M}_{500^{\circ} \mathrm{C}} \%^{\mathrm{d}}$ & $\mathrm{M}_{700^{\circ} \mathrm{C}} \%^{\mathrm{c}}$ & $\mathrm{M}_{900^{\circ} \mathrm{C}} \%^{\mathrm{d}}$ & $\mathrm{M}_{1000^{\circ} \mathrm{C}} \%^{\mathrm{d}}$ \\
\hline $1 c-G_{0}$ & 3 & 426 & $50.7^{\mathrm{e}}$ & 59.2 & 305 & 70.9 & 62.7 & 56.5 & 49.8 \\
\hline $1 c-G_{1}$ & 6 & 1423 & 55.6 & 55.7 & 329 & 80.8 & 66.7 & 57.0 & 43.0 \\
\hline $1 c-G_{3}$ & 24 & 7405 & 65.9 & 54.5 & 319 & 79.8 & 69.1 & 60.0 & 47.0 \\
\hline $1 c-G_{4}$ & 48 & 15381 & 67.2 & 54.4 & 326 & 79.6 & 68.8 & 60.7 & 48.0 \\
\hline $1 c-G_{5}$ & 96 & 31331 & 67.7 & 54.3 & 329 & 78.5 & 68.7 & 56.0 & 51.9 \\
\hline $\mathbf{1 c}-\mathbf{G}_{\mathbf{5}}$ under $\mathrm{O}_{2}$ & 96 & 31331 & 67.7 & 54.3 & 272 & 73.8 & 20.0 & 16.2 & 16.2 \\
\hline $1 b-G_{3}$ & 24 & 16766 & 29.1 & 36.1 & 228 & 17.8 & 9.7 & 7.0 & 7.0 \\
\hline $1 b-G_{5}$ & 96 & 68776 & 30.8 & 36.5 & 327 & 18.7 & 16.4 & 13.6 & 11.4 \\
\hline $1 g-G_{5}$ & 96 & 28643 & 74.2 & 55.4 & 350 & 52.2 & 45.3 & 34.4 & 20.7 \\
\hline $1 h-G_{5}$ & 96 & 47655 & 44.5 & 59.9 & 376 & 73.8 & 69.2 & 64.8 & 54.7 \\
\hline $1 \mathrm{i}-\mathbf{G}_{5}$ & 96 & 43832 & 48.5 & 52.0 & 228 & 52.8 & 45.8 & 38.9 & 35.1 \\
\hline $1 \mathrm{j}-\mathrm{G}_{5}$ & 96 & 47657 & 44.6 & 52.6 & 225 & 51.2 & 44.7 & 35.6 & 32.8 \\
\hline $1 \mathrm{k}-\mathrm{G}_{5}$ & 96 & 35368 & 60.0 & 54.6 & 270 & 67.4 & 60.2 & 50.2 & 48.7 \\
\hline $1 n-G_{5}$ & 96 & 39415 & 53.9 & 63.6 & 343 & 45.7 & 34.1 & 22.1 & 20.0 \\
\hline $2 d-G_{3}$ & 48 & 19260 & 50.8 & 44.9 & 275 & 62.1 & 28.8 & 6.6 & 2.3 \\
\hline $2 e-G_{3}$ & 48 & 19192 & 50.9 & 57.1 & 294 & 64.2 & 58.4 & 52.3 & 33.5 \\
\hline $2 f-G_{3}$ & 48 & 20943 & 46.7 & 52.3 & 211 & 63.0 & 50.0 & 32.7 & 23.5 \\
\hline $3 c-G_{3}$ & 24 & 7052 & 64.2 & 57.2 & 384 & 81.7 & 67.2 & 56.3 & 44.7 \\
\hline $4 c-G_{2}$ & 8 & 2525 & 66.7 & 56.1 & 348 & 86.8 & 80.6 & 76.5 & 70.0 \\
\hline $4 c-G_{3}$ & 16 & 5184 & 67.5 & 55.1 & 323 & 76.6 & 64.0 & 48.0 & 29.6 \\
\hline $4 I-G_{3}$ & 16 & 5425 & 64.6 & 56.2 & 268 & 63.7 & 59.8 & 50.4 & 42.4 \\
\hline $4 m-G_{3}$ & 16 & 5136 & 68.2 & 55.7 & 274 & 56.7 & 52.0 & 39.8 & 33.9 \\
\hline
\end{tabular}

Theoretical percentage of mass remaining after loss of all end groups by cleavage of the O-Aryl bonds.

b Percentage of carbon in the starting compound.

c Temperature to which the material retains $95 \%$ of its mass

d $\%$ of mass retained at $500^{\circ} \mathrm{C}, 700^{\circ} \mathrm{C}, 900^{\circ} \mathrm{C}$, or $1000^{\circ} \mathrm{C}$.

e Loss of two aryl groups.

${ }^{f}$ Loss of $\mathrm{Cl}$. 


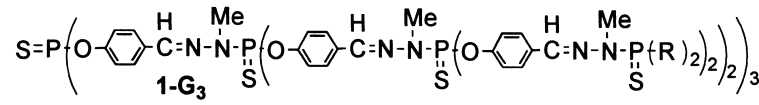

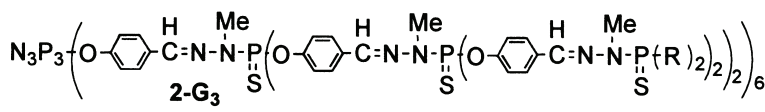

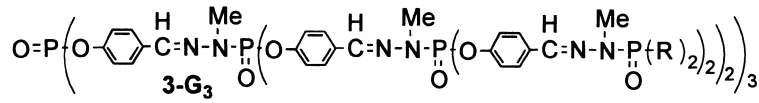

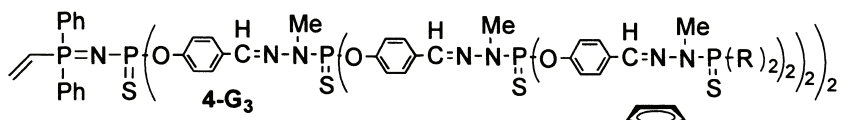

$$
\begin{aligned}
& \text { a: } \mathrm{R}=\mathrm{Cl} \\
& \text { b: } \mathrm{R}=0-\longrightarrow \mathrm{C}_{8} \mathrm{~F}_{17} \\
& \text { c: } \mathrm{R}=0-\mathrm{CHO}
\end{aligned}
$$

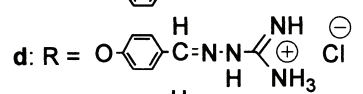

$$
\begin{aligned}
& \text { e: } \mathrm{R}=0-\| \mathrm{C}=\mathrm{N} \cdot \mathrm{N}-\mathrm{H}_{\mathrm{N}}^{\mathrm{H}}
\end{aligned}
$$

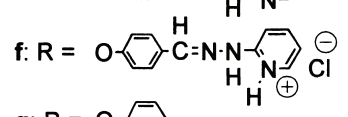

$$
\begin{aligned}
& \mathrm{h}: \mathrm{R}=\mathrm{O}-2-\mathrm{C}-\mathrm{C}_{\mathrm{Me}}^{\mathrm{Fe}} \\
& \text { i: } \mathrm{R}=0-\square-\mathrm{C}=\mathrm{N}-\dot{\mathrm{N}} \prod_{\mathrm{H}}^{\mathrm{Me}} \\
& j: R=0-\left\langle-C=N-\dot{N}_{H}\right. \\
& k: R=0-\underset{H}{\mathrm{C}}=\mathrm{C}-\mathrm{CO}_{2} \mathrm{H} \\
& \mathrm{I}: \mathrm{R}=0- \\
& \mathrm{m}: \mathrm{R}=\mathrm{O}-\mathrm{NM \textrm {T } _ { 2 }} \\
& n: \mathrm{R}=0-\longrightarrow \mathrm{C}_{8} \mathrm{H}_{17}
\end{aligned}
$$

Figure 2. Types of core, structure, and end groups.

dendrimers under oxygen. Figure 4 displays the comparison between $\mathbf{1 c}-\mathbf{G}_{\mathbf{5}}$ under $\mathrm{N}_{2}$ and under $\mathrm{O}_{2}$. Obviously, $\mathbf{1} \mathbf{c}-\mathbf{G}_{\mathbf{5}}$ is less stable under $\mathrm{O}_{2}$ : the degradation begins $60^{\circ} \mathrm{C}$ earlier, and the percentage of mass retained at $1000^{\circ} \mathrm{C}$ is only $16.2 \%$, compared with 51.9 under $\mathrm{N}_{2}$. However, the percentage of mass retained at $500^{\circ} \mathrm{C}$ is close in both cases: $78.5 \%$ under $\mathrm{N}_{2}$, and $73.8 \%$ under $\mathrm{O}_{2}$.

In order to know if the first degradation observed at 300$330^{\circ} \mathrm{C}$ under $\mathrm{N}_{2}$ was due to the structure of the dendrimer or the nature of the end groups, we decided to study the thermal behavior of dendrimers having various types of functionalized end groups. These experiments were all performed with the fifth generation dendrimer under an inert gas, in order to change only one parameter at a time. Nine compounds were used, i.e. $\mathbf{1 a - c - G _ { 5 }}, \mathbf{1 g}-\mathbf{k}-\mathbf{G}_{\mathbf{5}}$ and $\mathbf{1 n}-\mathbf{G}_{\mathbf{5}}$ (Fig. 5). Compound $\mathbf{1 g}-\mathbf{G}_{\mathbf{5}}$, which differs only from $\mathbf{1} \mathbf{c}-\mathbf{G}_{\mathbf{5}}$ by the absence of aldehyde end groups, was synthesized especially to check their influence on stability. It appears from the TGA curves that compound $\mathbf{1 g}-\mathbf{G}_{\mathbf{5}}$ is more stable $\left(T_{95 \%}=350^{\circ} \mathrm{C}\right)$ than $\mathbf{1} \mathbf{c}-\mathbf{G}_{\mathbf{5}}\left(T_{95 \%}=329^{\circ} \mathrm{C}\right)$, and presents a

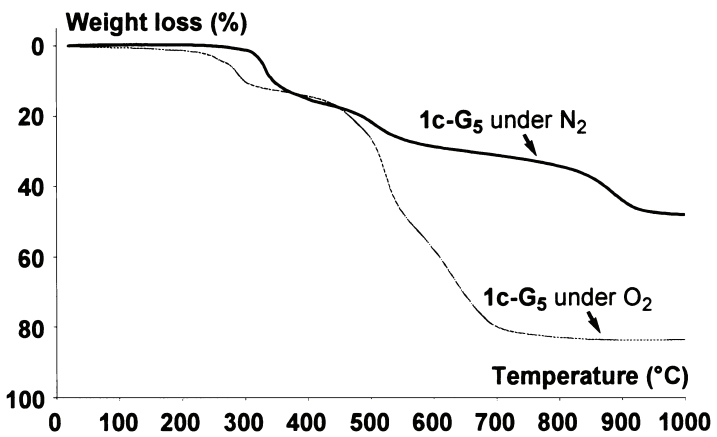

Figure 4. TGA curves of $\mathbf{1} \mathbf{c}-\mathbf{G}_{\mathbf{5}}$ under $\mathrm{N}_{2}$ and under $\mathrm{O}_{2}$.

single loss instead of two (compare Figs. 4 and 5). Thus, the first loss observed for $\mathbf{1} \mathbf{c}-\mathbf{G}_{\mathbf{5}}$ may be ascribed to the aldehyde groups, which might generate carbon monoxide. We have also tested six other compounds, all of generation five, with very different end group. Figure 5 shows that the thermal stability is highly dependent on the type of end groups. Indeed, the least stable compound $\left(\mathbf{1} \mathbf{j}-\mathbf{G}_{\mathbf{5}}\right)$ decomposes at $225^{\circ} \mathrm{C}$, whereas the most stable compound ( $\left.\mathbf{1 h}-\mathbf{G}_{\mathbf{5}}\right)$ decomposes at $376^{\circ} \mathrm{C}$. This last result indicates that it is not the internal structure of the dendrimers that is involved in the degradation observed at lower temperature, but the end groups.

In most cases, there is a rather good correlation between the percentage of mass retained at the level of the plateau observed between ca. 500 and $900^{\circ} \mathrm{C}$ and the theoretical value that should remain after the loss of all the Aryl end group, by cleavage of the $\mathrm{O}$-Aryl bonds (compare values from the columns ' $-\mathrm{Ar} \%$ ' and $M_{700{ }^{\circ} \mathrm{C}} \%$ in Table 1). However, there are a few noticeable exceptions. Dendrimer $\mathbf{1} \mathbf{a}-\mathbf{G}_{\mathbf{5}}$ differs from all the other $\mathbf{1}-\mathbf{G}_{\mathbf{5}}$, since it possesses chlorine atoms as end groups instead of $\mathrm{O}-\mathrm{Ar}$ end groups. If the value of the plateau corresponded to the cleavage of the $\mathrm{P}-\mathrm{Cl}$ bonds, it should be $85.3 \%$; if it corresponded to the cleavage of the internal $\mathrm{O}-\mathrm{Ar}\left(\mathrm{O}-\mathrm{C}_{6} \mathrm{H}_{4} \mathrm{CHNNMeP}(\mathrm{S}) \mathrm{Cl}_{2}\right)$, it should be $44.7 \%$. Both values are far from the value measured in the middle of the plateau at $700^{\circ} \mathrm{C}$ $\left(M_{700{ }^{\circ} \mathrm{C}} \%=67 \%\right)$; however, the cleavage of the $\mathrm{N}-$ $\mathrm{NMeP}(\mathrm{S}) \mathrm{Cl}_{2}$ bonds or of the $\mathrm{CH}=\mathrm{NNMeP}(\mathrm{S}) \mathrm{Cl}_{2}$ bonds gives values (66.1 and $63.2 \%$, respectively) close to the value measured. Analogous remarks can be made for the behavior of $\mathbf{1 g}-\mathbf{G}_{\mathbf{5}}$ (at $500^{\circ} \mathrm{C}$ ). Thus, besides the external $\mathrm{O}-$ Ar bonds, the hydrazone linkage appears as a second fragile point in these dendrimers, as already shown by mass

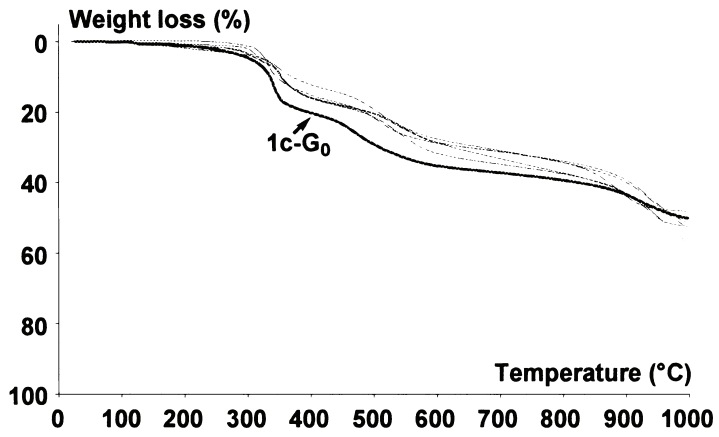

Figure 3. TGA curves for dendrimers $\mathbf{1} \mathbf{c}-\mathbf{G}_{\mathbf{0}}$ and $\mathbf{1} \mathbf{c}-\mathbf{G}_{\mathbf{1 - 5}}$ (thin lines).

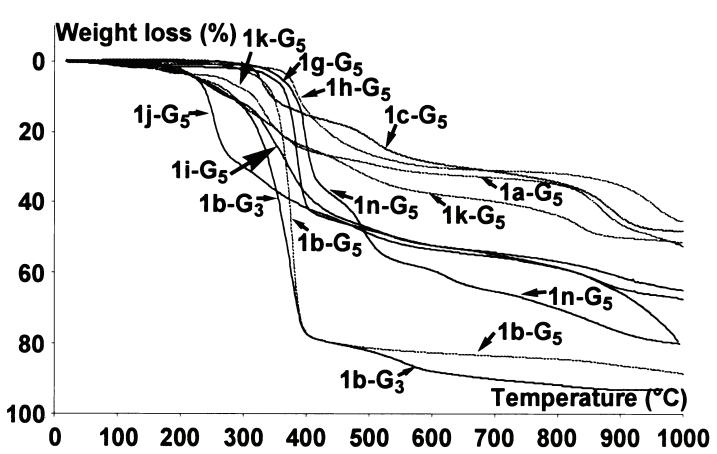

Figure 5. TGA curves of dendrimers $\mathbf{1 a - c - G _ { 5 }}, \mathbf{1 g}-\mathbf{k}-\mathbf{G}_{\mathbf{5}}$, and $\mathbf{1 b}-\mathbf{G}_{\mathbf{3}}$. 


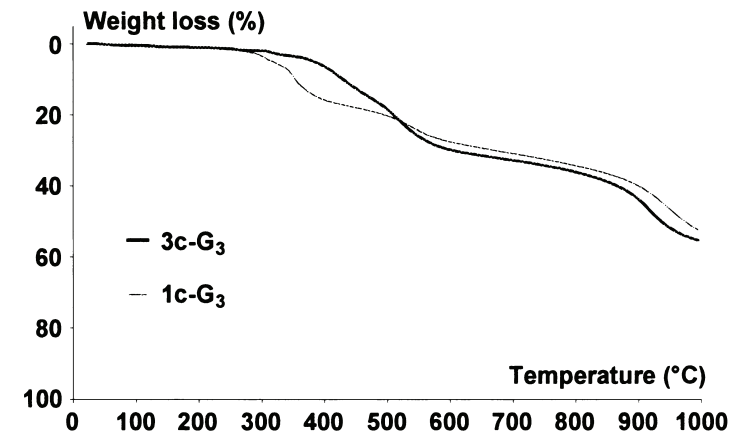

Figure 6. TGA curves for dendrimers $\mathbf{1} \mathbf{c}-\mathbf{G}_{\mathbf{3}}$ and $\mathbf{3} \mathbf{c}-\mathbf{G}_{\mathbf{3}}$.

spectrometry. ${ }^{17}$ On the other hand, it must be emphasized that the percentage of mass retained at $1000^{\circ} \mathrm{C}(47.6 \%)$ is much higher than the total percentage of carbon in $\mathbf{1 a - \mathbf { G } _ { \mathbf { 5 } }}$ $(38.7 \%)$. Thus, an important part of the heteroelements remains at $1000^{\circ} \mathrm{C}$.

Another 'abnormal' result concerns dendrimer $\mathbf{1 b}-\mathbf{G}_{\mathbf{5}}$, which decomposes abruptly and nearly totally. The percentage of mass remaining at the level of the plateau $\left(M_{700{ }^{\circ} \mathrm{C}} \%=16.4\right)$ is much lower than the value expected for the cleavage of the $\mathrm{O}-\mathrm{C}_{6} \mathrm{H}_{4} \mathrm{C}_{8} \mathrm{~F}_{17}$ end groups (30.8\%). To be sure that this behavior was due to the structure of the compound and not to a technical incident, we also performed the experiment with the third generation 1b$\mathbf{G}_{\mathbf{3}}$. This compound was even less stable than $\mathbf{1 b}-\mathbf{G}_{\mathbf{5}}$. However, both generations present an analogous behavior, which is totally unexpected in view of the chemical structure, except if one remembers that perfluorinated compounds have the ability to trap and carry oxygen. We postulate that the long perfluoroalkyl chains linked to the surface of $\mathbf{1} \mathbf{b}-\mathbf{G}_{\mathbf{x}}$ may trap oxygen, which induces the 'burning' of the dendrimer during the TGA experiments. In order to consolidate this assumption, an analogue of $\mathbf{1 b}-\mathbf{G}_{\mathbf{5}}$ in which all the fluorine atoms are replaced by hydrogen atoms was synthesized (compound $\mathbf{1 n}-\mathbf{G}_{\mathbf{5}}$ ). Both compounds have a different thermal behavior since $\mathbf{1} \mathbf{n}-\mathbf{G}_{\mathbf{5}}$ has a much higher percentage of mass remaining at $700^{\circ} \mathrm{C}$, as expected $\left(M_{700^{\circ} \mathrm{C}} \%=34.1\right)$. This assumption is also supported by the relatively close value obtained at $700^{\circ} \mathrm{C}$ for the TGA analysis of $\mathbf{1} \mathbf{c}-\mathbf{G}_{\mathbf{5}}$ under $\mathrm{O}_{2}\left(20 \%\right.$ for $\mathbf{1} \mathbf{c}-\mathbf{G}_{\mathbf{5}}$ under $\mathrm{O}_{2}$; $9.7 \%$ for $\mathbf{1} \mathbf{b}-\mathbf{G}_{\mathbf{3}} ; \mathbf{1 6 . 4 \%}$ for $\mathbf{1} \mathbf{b}-\mathbf{G}_{\mathbf{5}}$ ). The difference in stability observed between both generations tested could be due to a longer exposure to air of $\mathbf{1} \mathbf{b}-\mathbf{G}_{\mathbf{3}}$ compared to $\mathbf{1 b}-\mathbf{G}_{\mathbf{5}}$. The last data worthy of mention concern dendrimer $\mathbf{1} \mathbf{h}-\mathbf{G}_{\mathbf{5}}$, which is the most stable $\left(T_{95 \%}=376^{\circ} \mathrm{C}\right)$. It has also the

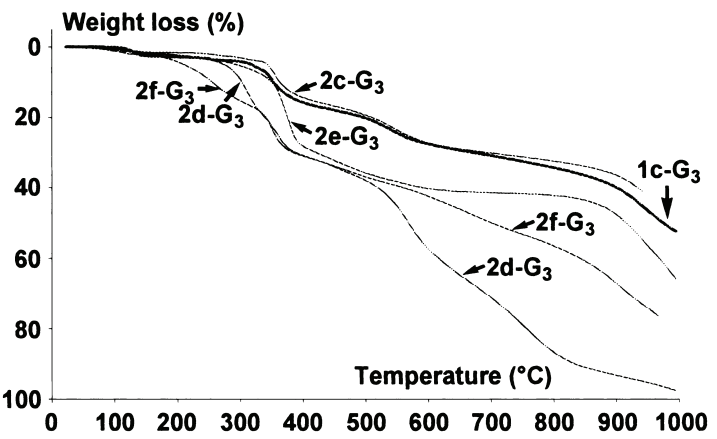

Figure 7. TGA curves for dendrimers $\mathbf{2} \mathbf{c}, \mathbf{e}-\mathbf{g}-\mathbf{G}_{\mathbf{3}}$ compared to $\mathbf{1 c}-\mathbf{G}_{\mathbf{3}}$.

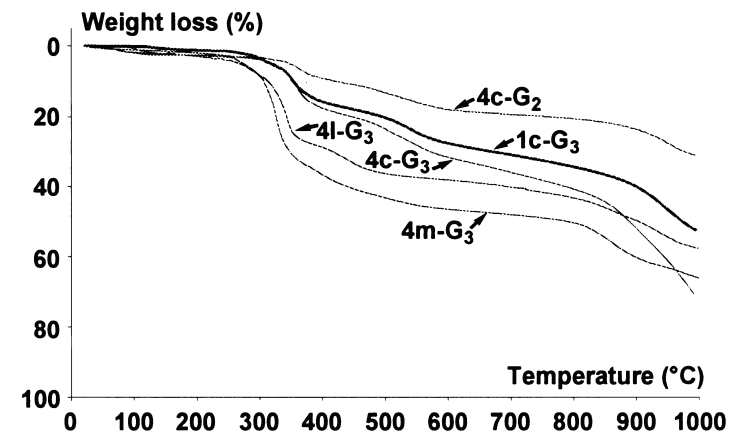

Figure 8. TGA curves for dendrons $\mathbf{4 c}-\mathbf{G}_{\mathbf{2}, 3}$ and $\mathbf{4 l}, \mathbf{m}-\mathbf{G}_{\mathbf{3}}$ compared to $\mathbf{1 c}$ G.

highest percentage of mass retained at $700^{\circ} \mathrm{C}(69.2 \%)$ as well as at $1000^{\circ} \mathrm{C}(54.7 \%)$. These values are much higher than the theoretical values corresponding to the cleavage of the $\mathrm{O}-\mathrm{Ar}$ surface bonds $(44.5 \%)$.

After studying the influence of the surface groups on stability, we wanted to check the influence of structural modifications, first by modifying the nature of the branching points. Indeed, our dendrimers have generally thiophosphoryl groups $(\mathrm{P}=\mathrm{S})$ as branching units, but they can also have phosphoryl groups $(\mathrm{P}=\mathrm{O})$. However, the latter generally induce a lower stability of the dendrimers upon long storage (several months), thus we generally use thiophosphoryl groups. Surprisingly, the comparison between the TGA analysis of $\mathbf{3} \mathbf{c}-\mathbf{G}_{\mathbf{3}}(\mathrm{P}=\mathrm{O}$ groups) and $\mathbf{1 c}-\mathbf{G}_{\mathbf{3}}\left(\mathrm{P}=\mathrm{S}\right.$ groups) shows that $\mathbf{3} \mathbf{c}-\mathbf{G}_{\mathbf{3}}$ is thermally more stable (Fig. 6). Indeed, the thermal degradation of $\mathbf{3} \mathbf{c}-\mathbf{G}_{\mathbf{3}}$ begins at $384^{\circ} \mathrm{C}$ instead of $319^{\circ} \mathrm{C}$ for $\mathbf{1} \mathbf{c}-\mathbf{G}_{\mathbf{3}}$ (Table 1).

Another way to induce structural modifications consists in using other types of cores. First, we chose to use the cyclotriphosphazene core $\left(\mathrm{N}_{3} \mathrm{P}_{3}\right)$ instead of the $\mathrm{P}=\mathrm{S}$ core, because it is well known that the thermal ring opening of cyclotriphosphazenes is one of the best methods to synthesise polyphosphazenes. ${ }^{16}$ This expected behaviour could induce a higher percentage of mass to be retained at high temperatures. However, comparison between $\mathbf{2} \mathbf{c}-\mathbf{G}_{3}$ and $\mathbf{1 c}-\mathbf{G}_{3}$, which differ only by the core and thus by the number of end groups, showed very similar behaviors (Fig. 7). We have also studied, for dendrimers built from the cyclotriphosphazene core, a few examples to check the influence of the end groups on stability. The pyridinium derivative $\mathbf{2} \mathbf{f}-\mathbf{G}_{\mathbf{3}}$ was the least stable compound in this series $\left(T_{95 \%}=211^{\circ} \mathrm{C}\right)$. This fact can be correlated with the low stability of the other pyridinium derivative $\mathbf{1} \mathbf{j}-\mathbf{G}_{\mathbf{5}}$ series. It is interesting to note that dendrimer $\mathbf{2} \mathbf{e}-\mathbf{G}_{\mathbf{3}}$, which differs only from $\mathbf{2} \mathbf{f}-\mathbf{G}_{\mathbf{3}}$ by the absence of proton on pyridine, is much more stable $\left(T_{95 \%}=294^{\circ} \mathrm{C}\right)$. Thus, it seems that the watersoluble cationic dendrimers are thermally less stable than the dendrimers soluble in organic solvents, presumably because of the ionization state of the end groups.

The absence of influence of the cyclotriphosphazene core on the thermal stability incited us to use another core, which could polymerize more easily. The $\mathrm{CH}_{2}=\mathrm{CH}-\mathrm{PPh}_{2}=\mathrm{N}-$ $\mathrm{P}=\mathrm{S}$ group located at the core of dendrons $\mathbf{4}-\mathbf{G}_{\mathbf{x}}$ appeared suitable for this purpose. The thermal behavior of $\mathbf{4} \mathbf{c}-\mathbf{G}_{\mathbf{3}}$ is almost identical to that of $\mathbf{1} \mathbf{c}-\mathbf{G}_{\mathbf{3}}$ (at least up to $500^{\circ} \mathrm{C}$ ) (Fig. 


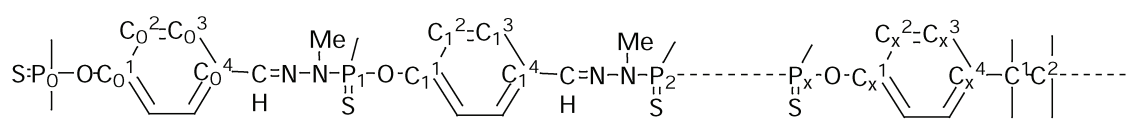

Figure 9. Numbering used for NMR.

8). On the other hand, a dramatic difference is observed for $\mathbf{4} \mathbf{c}-\mathbf{G}_{2}$. This second generation has an increased $\mathrm{T}_{95 \%}$ value $\left(323^{\circ} \mathrm{C}\right.$ for $\mathbf{4} \mathbf{c}-\mathbf{G}_{3}, 348^{\circ} \mathrm{C}$ for $\left.\mathbf{4} \mathbf{c}-\mathbf{G}_{2}\right)$, but the most spectacular difference concerns the percentage of mass retained at high temperature $\left(76.5 \%\right.$ at $900^{\circ} \mathrm{C}$ and $70.0 \%$ at $1000^{\circ} \mathrm{C}$ ). These are the highest values observed for all the compounds we have tested, and also for all dendrimers whose TGA behavior was previously reported. To explain this particular behavior, we think that the polymerization of the vinyl group located at the core occurs as expected for $\mathbf{4 c -}$ $\mathbf{G}_{2}$, but not for $\mathbf{4} \mathbf{c}-\mathbf{G}_{3}$, because of increased steric hindrance. The presence of dimethylamino groups $\left(\mathbf{4} \mathbf{l}-\mathbf{G}_{3}\right)$ or nitrile groups $\left(\mathbf{4} \mathbf{m}-\mathbf{G}_{3}\right)$ on the surface of the dendron induces a lower stability compared to the aldehyde groups.

\section{Conclusion}

The reported TGA analysis of 24 phosphorus-containing dendrimers and dendrons allows conclusions to be drawn about the thermal stability of these compounds. The most important point is that the internal structure of these dendrimers is stable up to at least $376^{\circ} \mathrm{C}$ for the thiophosphoryl dendrimers ( $\mathrm{P}=\mathrm{S}$ as branching points), and even up to $384^{\circ} \mathrm{C}$ for the phosphoryl dendrimers $(\mathrm{P}=\mathrm{O}$ as branching points). These are high values. Furthermore, there is practically no influence of the generation on the thermal stability. In fact, the most important point concerning stability is the nature of the end groups. Indeed, for the thiophosphoryl dendrimers, the thermal stability ranges from 225 to $376^{\circ} \mathrm{C}$, depending on the end groups. It appears that the least stable compounds are the cationic dendrimers soluble in water, particularly the pyridinium derivatives. However, the most important use of water-soluble dendrimers concerns biology, and stability under $225^{\circ} \mathrm{C}$ is sufficient for such purposes. On the other hand, the stability of most phosphorus-containing dendrimers soluble in organic solvents is over $300^{\circ} \mathrm{C}$. We have also shown that the nature of the core has practically no influence on the thermal behavior, however, with one noticeable exception. A second generation dendron having a vinyl group at the core, able to polymerize, retains $70 \%$ of its mass at $1000^{\circ} \mathrm{C}$. This very unusual behavior offers interesting perspectives for novel surface coating materials. Thus, it appears from all these data that phosphorus-containing dendrimers offer an excellent compromise between thermal stability and ease of functionalization.

\section{Experimental}

\subsection{General}

All manipulations were carried out with standard highvacuum and dry-argon techniques. ${ }^{1} \mathrm{H},{ }^{13} \mathrm{C},{ }^{31} \mathrm{P}$ NMR and ${ }^{19} \mathrm{~F}$ spectra were recorded with Bruker AC 200, AC 250, DPX 300, or AMX 400 spectrometers. References for NMR chemical shifts are $85 \% \mathrm{H}_{3} \mathrm{PO}_{4}$ for ${ }^{31} \mathrm{P} \mathrm{NMR}, \mathrm{SiMe}_{4}$ for ${ }^{1} \mathrm{H}$ and ${ }^{13} \mathrm{C}$ NMR and $\mathrm{CF}_{3} \mathrm{CO}_{2} \mathrm{H}$ for ${ }^{19} \mathrm{~F}$. The attribution of ${ }^{13} \mathrm{C}$ NMR signals has been done using Jmod, two-dimensional HBMC and HMQC, broad band, or $\mathrm{CW}{ }^{31} \mathrm{P}$ decoupling experiments when necessary. The numbering used for NMR is depicted in Figure 9. TGA measurements were recorded on a TGA7 Perkin-Elmer or Setaram 92.16.18 apparatus operating between 20 and $1500^{\circ} \mathrm{C}$. Curves were recorded between 20 and $1000^{\circ} \mathrm{C}\left(20^{\circ} \mathrm{C} \mathrm{min}^{-1}\right)$ using an $\mathrm{Al}_{2} \mathrm{O}_{3}$ sample boat, and helium or nitrogen as a vector $\left(1 \mathrm{l} \mathrm{h}^{-1}\right)$. All dendrimers were synthesized in our laboratory, according to the procedures we previously reported $\left(\mathbf{1} \mathbf{a}-\mathbf{G}_{\mathbf{x}}\right.$ and

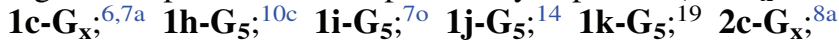

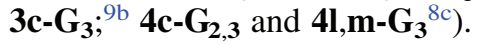

\subsection{General procedure for the synthesis of dendrimers $1 \mathrm{~b}-\mathrm{G}_{\mathrm{x}}(\mathrm{x}=1,2,3,4,5)$}

To a solution containing $200 \mathrm{mg}$ of dendrimer $\mathbf{1 b}-\mathbf{G}_{\mathbf{x}}(\mathbf{x}=1$, $0.220 \mathrm{mmol} ; \mathbf{x}=2,0.084 \mathrm{mmol} ; \mathbf{x}=3,0.037 \mathrm{mmol} ; \mathbf{x}=4$, $0.018 \mathrm{mmol} ; \mathbf{x}=5,0.009 \mathrm{mmol})$ in a mixture of $\mathrm{CFC} 113$ $\left(\mathrm{ClF}_{2} \mathrm{CCFCl}_{2}\right)(10 \mathrm{~mL})$ and $\mathrm{THF}(10 \mathrm{~mL})$ was added dropwise a solution of THF $(10 \mathrm{~mL})$ containing the sodium salt of 4-perfluorooctylphenol $(\mathbf{x}=1,775 \mathrm{mg}, 1.452 \mathrm{mmol}$; $\mathbf{x}=2,593 \mathrm{mg}, 1.110 \mathrm{mmol} ; \mathbf{x}=3,522 \mathrm{mg}, 0.977 \mathrm{mmol}$; $\mathbf{x}=4,508 \mathrm{mg}, 0.950 \mathrm{mmol} ; \mathbf{x}=5,508 \mathrm{mg}, 0.950 \mathrm{mmol})$. The reaction mixture was stirred overnight at room temperature and then centrifuged to remove sodium chloride. After solvent removal under reduced pressure the crude material was washed with a mixture of ether and pentane (1/1, $3 \times 10 \mathrm{~mL}$ ) to afford the expected perfluorinated dendrimers $\mathbf{1 b}-\mathbf{G}_{\mathbf{x}}$ as white powders.

4.2.1. First generation $\mathbf{1 b}-\mathbf{G}_{\mathbf{1}} \cdot 90 \%$ Yield; ${ }^{31} \mathrm{P}\left\{{ }^{1} \mathrm{H}\right\} \mathrm{NMR}$ $\left(\mathrm{CDCl}_{3}\right) \delta 52.1\left(\mathrm{~s}, \mathrm{P}_{0}\right), 60.7\left(\mathrm{~s}, \mathrm{P}_{1}\right) ;{ }^{1} \mathrm{H} \mathrm{NMR}\left(\mathrm{CDCl}_{3}\right) \delta 3.42$ $\left(\mathrm{d},{ }^{3} J_{\mathrm{HP}}=10.8 \mathrm{~Hz}, 9 \mathrm{H}, \mathrm{N}-\mathrm{CH}_{3}\right), 7.1-7.8(\mathrm{~m}, 36 \mathrm{H}, \mathrm{Ar}$, $\mathrm{CH}=\mathrm{N}) ;{ }^{19} \mathrm{~F} \mathrm{NMR}\left(\mathrm{CDCl}_{3}\right) \delta-50.5\left(\right.$ br s, $\left.12 \mathrm{~F}, \mathrm{C}^{7} \mathrm{~F}_{2}\right)$, -47.0 (br s, 12F, $\mathrm{C}^{6} \mathrm{~F}_{2}$ ), -46.1 (br s, 18F, $\mathrm{C}^{2,3,4} \mathrm{~F}_{2}$ ), -45.6 (br s, $12 \mathrm{~F}, \mathrm{C}^{5} \mathrm{~F}_{2}$ ), $-34.6\left(\mathrm{t},{ }^{3} J_{\mathrm{FF}}=14 \mathrm{~Hz}, 12 \mathrm{~F}, \mathrm{C}^{1} \mathrm{~F}_{2}\right),-5.2$ $\left(\mathrm{t},{ }^{3} J_{\mathrm{FF}}=10 \mathrm{~Hz}, 18 \mathrm{~F}, \mathrm{C}^{8} \mathrm{~F}_{3}\right) ;{ }^{13} \mathrm{C}\left\{{ }^{1} \mathrm{H}\right\} \mathrm{NMR}\left(\mathrm{CDCl}_{3}\right) \delta 32.8$ $\left(\mathrm{d},{ }^{2} J_{\mathrm{CP}}=13.5 \mathrm{~Hz}, \mathrm{~N}-\mathrm{CH}_{3}\right), 103-121\left(\mathrm{~m}, \mathrm{C}^{i}-\mathrm{F}\right), 121.6(\mathrm{~d}$, $\left.{ }^{3} J_{\mathrm{CP} 0,1}=4.6 \mathrm{~Hz}, \mathrm{C}_{0,1}^{2}\right), 126.1\left(\mathrm{t},{ }^{2} J_{\mathrm{CF}}=24.7 \mathrm{~Hz}, \mathrm{C}_{1}^{4}\right), 128.5(\mathrm{~s}$, $\left.\mathrm{C}_{0}^{3}\right), 128.6\left(\mathrm{t},{ }^{3} J_{\mathrm{CF}}=7.7 \mathrm{~Hz}, \mathrm{C}_{1}^{3}\right), 132.4\left(\mathrm{~s}, \mathrm{C}_{0}^{4}\right), 139.1(\mathrm{~d}$, $\left.{ }^{3} J_{\mathrm{CP} 1}=13.8 \mathrm{~Hz}, \mathrm{CH}=\mathrm{N}\right), 151.4\left(\mathrm{~d},{ }^{2} J_{\mathrm{CP} 0}=7.8 \mathrm{~Hz}, \mathrm{C}_{0}^{1}\right)$, $153.3\left(\mathrm{~d},{ }^{2} J_{\mathrm{CP} 1}=6.3 \mathrm{~Hz}, \mathrm{C}_{1}^{1}\right)$. Calcd for $\mathrm{C}_{108} \mathrm{H}_{48} \mathrm{~F}_{102} \mathrm{~N}_{6} \mathrm{O}_{9-}$ $\mathrm{P}_{4} \mathrm{~S}_{4}$ (3764): C, 34.47; H, 1.29; N, 2.23. Found: C, 34.51; H, $1.26 ; \mathrm{N}, 2.29$.

4.2.2. Second generation $\mathbf{1 b}-\mathbf{G}_{2}$. $95 \%$ Yield; ${ }^{31} \mathrm{P}\left\{{ }^{1} \mathrm{H}\right\}$ $\operatorname{NMR}\left(\mathrm{CDCl}_{3} / \mathrm{CFC} 113,1 / 1\right) \delta 53.3\left(\mathrm{~s}, \mathrm{P}_{0}\right), 61.3\left(\mathrm{~s}, \mathrm{P}_{2}\right), 62.4$ $\left(\mathrm{s}, \mathrm{P}_{1}\right) ;{ }^{19} \mathrm{~F} \mathrm{NMR}\left(\mathrm{CDCl}_{3} / \mathrm{CFC} 113,1 / 1\right) \delta-50.6$ (br s, $24 \mathrm{~F}$, $\mathrm{C}^{7} \mathrm{~F}_{2}$ ), -47.1 (br s, 24F, $\mathrm{C}^{6} \mathrm{~F}_{2}$ ), -46.2 (br s, 36F, $\mathrm{C}^{2,3,4} \mathrm{~F}_{2}$ ), -45.6 (br s, 24F, $\mathrm{C}^{5} \mathrm{~F}_{2}$ ), -34.8 (br s, 24F, $\mathrm{C}^{1} \mathrm{~F}_{2}$ ), -5.4 (br s, $\left.36 \mathrm{~F}, \mathrm{C}^{8} \mathrm{~F}_{3}\right)$; ${ }^{1} \mathrm{H}$ NMR $\left(\mathrm{CDCl}_{3} / \mathrm{CFC} 113,1 / 1\right) \delta 3.42(\mathrm{bd}$, $\left.{ }^{3} J_{\mathrm{HP}}=10.0 \mathrm{~Hz}, 27 \mathrm{H}, \mathrm{N}-\mathrm{CH}_{3}\right), 7.1-7.8(\mathrm{~m}, 93 \mathrm{H}, \mathrm{Ar}$, $\mathrm{CH}=\mathrm{N}$ ). Calcd for $\mathrm{C}_{240} \mathrm{H}_{120} \mathrm{~F}_{204} \mathrm{~N}_{18} \mathrm{O}_{21} \mathrm{P}_{10} \mathrm{~S}_{10}$ (8098): $\mathrm{C}$, 35.60; H, 1.49; N, 3.11. Found: C, 35.78; H, 1.56; N, 3.22. 
4.2.3. Third generation $\mathbf{1 b}-\mathbf{G}_{3} \cdot 93 \%$ Yield; ${ }^{31} \mathrm{P}\left\{{ }^{1} \mathrm{H}\right\} \mathrm{NMR}$ $\left(\mathrm{CDCl}_{3} / \mathrm{CFC} 113,1 / 1\right) \delta 53.3\left(\mathrm{~s}, \mathrm{P}_{0}\right), 61.4\left(\mathrm{~s}, \mathrm{P}_{3}\right), 62.2(\mathrm{~s}$, $\left.\mathrm{P}_{1}\right), 62.2\left(\mathrm{~s}, \mathrm{P}_{2}\right) ;{ }^{1} \mathrm{H} \mathrm{NMR}\left(\mathrm{CDCl}_{3} / \mathrm{CFC} 113,1 / 1\right) \delta 3.33(\mathrm{bd}$, $\left.{ }^{3} J_{\mathrm{HP}}=10.0 \mathrm{~Hz}, 63 \mathrm{H}, \mathrm{N}-\mathrm{CH}_{3}\right), 7.1-7.7(\mathrm{~m}, 201 \mathrm{H}, \mathrm{Ar}$, $\mathrm{CH}=\mathrm{N}) ;{ }^{19} \mathrm{~F}$ NMR $\left(\mathrm{CDCl}_{3} / \mathrm{CFC} 113,1 / 1\right) \delta-50.3$ (br s, $48 \mathrm{~F}, \mathrm{C}^{7} \mathrm{~F}_{2}$ ), -46.9 (br s, 48F, $\mathrm{C}^{6} \mathrm{~F}_{2}$ ), -46.0 (br s, 72F, $\mathrm{C}^{2,3,4} \mathrm{~F}_{2}$ ), -45.5 (br s, $48 \mathrm{~F}, \mathrm{C}^{5} \mathrm{~F}_{2}$ ), -34.5 (br s, $48 \mathrm{~F}, \mathrm{C}^{1} \mathrm{~F}_{2}$ ), -4.9 (br s, 72F, $\mathrm{C}^{8} \mathrm{~F}_{3}$ ). Calcd for $\mathrm{C}_{504} \mathrm{H}_{264} \mathrm{~F}_{408} \mathrm{~N}_{42} \mathrm{O}_{45} \mathrm{P}_{22-}$ $\mathrm{S}_{22}$ (16766): C, 36.11; H, 1.59; H, 3.51. Found: C, 36.23; H, $1.49 ; \mathrm{N}, 3.42$.

4.2.4. Fourth generation $\mathbf{1 b}-\mathbf{G}_{\mathbf{4}} \cdot 96 \%$ Yield; ${ }^{31} \mathrm{P}\left\{{ }^{1} \mathrm{H}\right\}$ $\mathrm{NMR}\left(\mathrm{CDCl}_{3} / \mathrm{CFC} 113,1 / 1\right) \delta 53.0\left(\mathrm{~s}, \mathrm{P}_{0}\right), 61.3\left(\mathrm{~s}, \mathrm{P}_{4}\right), 62.2$ $\left(\mathrm{s}, \mathrm{P}_{1}\right), 62.5\left(\mathrm{~s}, \mathrm{P}_{3}\right), 62.6\left(\mathrm{~s}, \mathrm{P}_{2}\right) ;{ }^{1} \mathrm{H} \mathrm{NMR}\left(\mathrm{CDCl}_{3} / \mathrm{CFC} 113\right.$, 1/1) $\delta 3.30\left(\right.$ br s, $\left.135 \mathrm{H}, \mathrm{N}-\mathrm{CH}_{3}\right), 7.2-7.8(\mathrm{~m}, 417 \mathrm{H}, \mathrm{Ar}$, $\mathrm{CH}=\mathrm{N}) ;{ }^{19} \mathrm{~F} \mathrm{NMR}\left(\mathrm{CDCl}_{3} / \mathrm{CFC} 113,1 / 1\right) \delta-50.7$ (br s, 96F, $\mathrm{C}^{7} \mathrm{~F}_{2}$ ), -47.2 (br s, 96F, $\mathrm{C}^{6} \mathrm{~F}_{2}$ ), -46.2 (br s, 144F, $\mathrm{C}^{2,3,4} \mathrm{~F}_{2}$ ), -45.7 (br s, 96F, $\mathrm{C}^{5} \mathrm{~F}_{2}$ ), -34.8 (br s, 96F, $\mathrm{C}^{1} \mathrm{~F}_{2}$ ), -5.5 (br s, 144F, $\mathrm{C}^{8} \mathrm{~F}_{3}$ ). Calcd for $\mathrm{C}_{1032} \mathrm{H}_{552} \mathrm{~F}_{816} \mathrm{~N}_{90} \mathrm{O}_{93^{-}}$ $\mathrm{P}_{46} \mathrm{~S}_{46}$ (34102): C, 36.35; H, 1.63; N, 3.70. Found: C, 36.42; $\mathrm{H}, 1.71 ; \mathrm{N}, 3.80$.

4.2.5. Fifth generation $\mathbf{1 b}-\mathbf{G}_{\mathbf{5}} \cdot 95 \%$ Yield; ${ }^{31} \mathrm{P}\left\{{ }^{1} \mathrm{H}\right\} \mathrm{NMR}$ $\left(\mathrm{CDCl}_{3} / \mathrm{CFC} 113,1 / 1\right) \delta 52.9\left(\mathrm{~s}, \mathrm{P}_{0}\right), 61.4\left(\mathrm{~s}, \mathrm{P}_{5}\right), 62.4(\mathrm{~s}$, $\left.\mathrm{P}_{1,2,3,4}\right) ;{ }^{1} \mathrm{H} \mathrm{NMR}\left(\mathrm{CDCl}_{3} / \mathrm{CFC} 113,1 / 1\right) \delta 3.27$ (br s, $279 \mathrm{H}$, $\left.\mathrm{N}-\mathrm{CH}_{3}\right), 7.1-7.8(\mathrm{~m}, 849 \mathrm{H}, \mathrm{Ar}, \mathrm{CH}=\mathrm{N}) ;{ }^{19} \mathrm{~F} \mathrm{NMR}\left(\mathrm{CDCl}_{3} /\right.$ $\mathrm{CFC} 113,1 / 1) \delta-50.8$ (br s, $192 \mathrm{~F}, \mathrm{C}^{7} \mathrm{~F}_{2}$ ), -47.3 (br s, 192F, $\mathrm{C}^{6} \mathrm{~F}_{2}$ ), -46.4 (br s, 288F, $\mathrm{C}^{2,3,4} \mathrm{~F}_{2}$ ), -45.8 (br s, 192F, $\mathrm{C}^{5} \mathrm{~F}_{2}$ ), -34.8 (br s, $192 \mathrm{~F}, \mathrm{C}^{1} \mathrm{~F}_{2}$ ), -5.7 (br s, 288F, $\mathrm{C}^{8} \mathrm{~F}_{3}$ ). Calcd for $\mathrm{C}_{2088} \mathrm{H}_{1128} \mathrm{~F}_{1632} \mathrm{~N}_{186} \mathrm{O}_{189} \mathrm{P}_{94} \mathrm{~S}_{94}$ (68776): C, 36.46; H, 1.65; N, 3.79. Found: C, 36.51; H, 1.72; N, 3.82.

\subsection{Synthesis and characterization of dendrimer $\mathbf{1 g}^{-G_{5}}$}

To $0.200 \mathrm{~g}(8.655 \mu \mathrm{mol})$ of $\mathbf{1 a - G _ { 5 }}$ in $5 \mathrm{~mL}$ of freshly distilled THF was added $0.106 \mathrm{~g}(0.091 \mathrm{mmol})$ of the sodium salt of phenol. The resulting mixture was stirred overnight at room temperature. Then, the sodium chloride formed was removed by centrifugation. The resulting solution was evaporated under vacuum and the residue was washed three times with ether to give $\mathbf{1 g - \mathbf { G } _ { \mathbf { 5 } }}$ as a white powder in $95 \%$ yield.

${ }^{31} \mathrm{P}\left\{{ }^{1} \mathrm{H}\right\} \operatorname{NMR}\left(\mathrm{CDCl}_{3}\right) \delta 65.8\left(\mathrm{~s}, \mathrm{P}_{1-2-3-4}\right), 66.0\left(\mathrm{~s}, \mathrm{P}_{5}\right) ;{ }^{1} \mathrm{H}$ $\mathrm{NMR}\left(\mathrm{CDCl}_{3}\right) \delta 3.3\left(\right.$ br s, $\left.279 \mathrm{H}, \mathrm{CH}_{3}\right), 7.1-7.9(\mathrm{~m}, 945 \mathrm{H}$, $\mathrm{Ar}$ and $\mathrm{CH}=\mathrm{N}) ;{ }^{13} \mathrm{C}\left\{{ }^{1} \mathrm{H}\right\}$ NMR $\left(\mathrm{CDCl}_{3}\right) \delta 33.1 \quad(\mathrm{~d}$, $\left.{ }^{2} J_{\mathrm{CP}}=12.9 \mathrm{~Hz}, \mathrm{CH}_{3}-\mathrm{N}-\mathrm{P}_{1-2-3-4-5}\right), 121.4\left(\mathrm{~d},{ }^{3} J_{\mathrm{CP}}=3.5 \mathrm{~Hz}\right.$, $\left.\mathrm{C}_{5}^{2}\right), 121.8\left(\mathrm{~s}, \mathrm{C}_{0-1-2-3-4}^{2}\right), 125.4\left(\mathrm{~s}, \mathrm{C}_{5}^{4}\right), 128.3$ (s, $\left.\mathrm{C}_{0-1-2-3-4}^{3}\right)$, $129.5\left(\mathrm{~s}, \mathrm{C}_{5}^{3}\right), 132.3\left(\mathrm{~s}, \mathrm{C}_{0-1-2-3-4}^{4}\right), 138.5\left(\mathrm{~d},{ }^{3} J_{\mathrm{CP}}=13.6 \mathrm{~Hz}\right.$, $\left.\mathrm{C}_{4}^{4}-\mathrm{CH}=\mathrm{N}\right), 139.1\left(\mathrm{~d},{ }^{3} J_{\mathrm{CP}}=12.8 \mathrm{~Hz}, \mathrm{C}_{0-1-2-3}^{4}-\mathrm{CH}=\mathrm{N}\right)$, $150.6\left(\mathrm{~d},{ }^{2} J_{\mathrm{CP}}=7.1 \mathrm{~Hz}, \mathrm{C}_{5}^{1}\right), 151.2\left(\mathrm{~d},{ }^{2} J_{\mathrm{CP}}=6.3 \mathrm{~Hz}\right.$, $\mathrm{C}_{0-1-2-3-4}^{1}$ ). Calcd for $\mathrm{C}_{1320} \mathrm{H}_{1224} \mathrm{~N}_{186} \mathrm{O}_{189} \mathrm{P}_{94} \mathrm{~S}_{94}$ (28643): C, 55.35; H, 4.31; N, 9.10. Found: C, 55.49; H, 4.42; N, 8.97 .

\subsection{Synthesis and characterization of dendrimer $1 \mathbf{n}^{-G_{5}}$}

To a solution containing $100 \mathrm{mg}$ of dendrimer $\mathbf{1 a - G _ { \mathbf { 5 } }}$ $(0.0045 \mathrm{mmol})$ in THF was added dropwise a solution of THF $(10 \mathrm{~mL})$ containing the sodium salt of 4-octylphenol (110 $\mathrm{mg}, 0.482 \mathrm{mmol})$. The reaction mixture was stirred overnight at room temperature and then centrifuged to remove sodium chloride. After solvent removal under reduced pressure the crude material was washed with pure pentane to afford the expected dendrimer $\mathbf{1} \mathbf{n}-\mathbf{G}_{\mathbf{5}}$ as a white powder. 90\% Yield; ${ }^{31} \mathrm{P}\left\{{ }^{1} \mathrm{H}\right\}$ NMR $\left(\mathrm{CDCl}_{3}\right) 52.8\left(\mathrm{~s}, \mathrm{P}_{0}\right)$, 62.4 (s, $\left.\mathrm{P}_{1,2,3,4}\right), 63.0\left(\mathrm{~s}, \mathrm{P}_{5}\right) ;{ }^{1} \mathrm{H}$ NMR $\left(\mathrm{CDCl}_{3}\right) 0.88$ (br s, $288 \mathrm{H}, \mathrm{CH}_{3}$ ), 1.27 (br s, $960 \mathrm{H}, \mathrm{CH}_{2}$ ), 1.56 (br s, $192 \mathrm{H}, \mathrm{CH}_{2}$ ), 2.54 (br s, $192 \mathrm{H}, \mathrm{CH}_{2}$ ), 3.31 (br s, $279 \mathrm{H}, \mathrm{N}-\mathrm{CH}_{3}$ ), 7.1-7.8 $(\mathrm{m}, 849 \mathrm{H}, \mathrm{Ar}, \mathrm{CH}=\mathrm{N}) ;{ }^{13} \mathrm{C}\left\{{ }^{1} \mathrm{H}\right\}$ NMR $\left(\mathrm{CDCl}_{3}\right) 14.4(\mathrm{~s}$, $\left.\mathrm{CH}_{3}\right), 23.0\left(\mathrm{~s}, \mathrm{CH}_{2}\right), 29.6\left(\mathrm{~s}, \mathrm{CH}_{2}\right), 29.7\left(\mathrm{~s}, \mathrm{CH}_{2}\right), 29.8$ (s, $\left.\mathrm{CH}_{2}\right), 31.8\left(\mathrm{~s}, \mathrm{CH}_{2}\right), 32.3\left(\mathrm{~s}, \mathrm{CH}_{2}\right), 33.4\left(\mathrm{~d},{ }^{2} \mathrm{~J}_{\mathrm{CP}}=12.7 \mathrm{~Hz}\right.$, $\left.\mathrm{N}-\mathrm{CH}_{3}\right), 35.7\left(\mathrm{~s}, \mathrm{CH}_{2}-\mathrm{Ar}\right), 121.5\left(\mathrm{~d},{ }^{3} J_{\mathrm{CP}}=4.3 \mathrm{~Hz}, \mathrm{C}_{5}^{2}\right)$, 122.2 (br s, $\mathrm{C}_{0,1,2,3,4}^{2}$ ), 128.6 (br s, $\mathrm{C}_{4}^{3}$ ), 128.7 (br s, $\mathrm{C}_{0,1,2,3}^{3}$ ), 129.7 (s, C 3 ), 132.6 (s, $\left.\mathrm{C}_{0,1,2,3}^{4}\right), 132.8$ (s, C 4 ), 138.7 (br d, ${ }^{3} J_{\mathrm{CP}}=13.1 \mathrm{~Hz}, \mathrm{CH}=\mathrm{N}-\mathrm{N}-\mathrm{P}_{5}$ ), 138.7 (br d, ${ }^{3} J_{\mathrm{CP}}=13.1 \mathrm{~Hz}$, $\left.\mathrm{CH}=\mathrm{N}-\mathrm{N}-\mathrm{P}_{1,2,3,4}\right), 140.4\left(\mathrm{~s}, \mathrm{C}_{5}^{4}\right), 148.9\left(\mathrm{~d},{ }^{2} J_{\mathrm{CP}}=7.2 \mathrm{~Hz}\right.$, $\mathrm{C}_{5}^{1}$ ), $151.6\left(\mathrm{br} \mathrm{d},{ }^{2} J_{\mathrm{CP}}=7.1 \mathrm{~Hz}, \mathrm{C}_{0,1,2,3,4}^{1}\right)$. Calcd for $\mathrm{C}_{2088} \mathrm{H}_{2760} \mathrm{~N}_{186} \mathrm{O}_{189} \mathrm{P}_{94} \mathrm{~S}_{94}$ (39415): C, 63.63; H, 7.06; $\mathrm{N}$, 6.61. Found: C, 63.72; H, 7.13; N, 6.51 .

\subsection{Synthesis and characterization of dendrimer $\mathbf{2 d}-\mathbf{G}_{\mathbf{3}}$}

To a warm solution $\left(T=60^{\circ} \mathrm{C}\right)$ containing $1.00 \mathrm{~g}$ $(67.5 \mu \mathrm{mol})$ of dendrimer $\mathbf{2} \mathbf{c}-\mathbf{G}_{\mathbf{3}}$ in THF (15 mL) was added dropwise a small excess of aminoguanidinium chloride (359 mg, $3.25 \mathrm{mmol}$ ) in solution in warm methanol $(5 \mathrm{~mL})$. After addition, the system was stirred at $80^{\circ} \mathrm{C}$ under pressure for $48 \mathrm{~h}$ then concentrated under vacuum. The remaining oil was precipitated with cold pentane. After filtration, the white solid obtained was washed with $\mathrm{Et}_{2} \mathrm{O}$ $(3 \times 20 \mathrm{~mL})$. Removal of the small excess of aminoguanidinium hydrochloride was accomplished by redissolving the white solid in water and stirring the resulting solution overnight with Aldrich Scavengepore ${ }^{\circledR}$ 4-phenetoxybenzaldehyde-terminated resin. After filtration and evaporation of water, the guanidinium-terminated dendrimer $\mathbf{2} \mathbf{d}-\mathbf{G}_{\mathbf{3}}$ was obtained as a white powder in $89 \%$ yield $(1.16 \mathrm{~g}) .{ }^{31} \mathrm{P}\left\{{ }^{1} \mathrm{H}\right\}$ NMR $\left(\mathrm{D}_{2} \mathrm{O}\right) \delta 10.2\left(\mathrm{~s}, \mathrm{P}_{0}\right), 63.1\left(\mathrm{br} \mathrm{s}, \mathrm{P}_{1}, \mathrm{P}_{2}, \mathrm{P}_{3}\right) ;{ }^{1} \mathrm{H}$ NMR $\left(\mathrm{D}_{2} \mathrm{O} / \mathrm{CD}_{3} \mathrm{CN}\right) \delta 3.28\left(\mathrm{~m}, 126 \mathrm{H}, \mathrm{CH}_{3} \mathrm{NP}_{1-3}\right), 6.02(\mathrm{br} \mathrm{s}$, $240 \mathrm{H}, \mathrm{NH}), 8.2-9.6(\mathrm{~m}, 450 \mathrm{H}, \mathrm{ArH}, \mathrm{CH}=\mathrm{N}) ;{ }^{13} \mathrm{C}\left\{{ }^{1} \mathrm{H}\right\}$ NMR $\left(\mathrm{D}_{2} \mathrm{O} / \mathrm{CD}_{3} \mathrm{CN}\right) \delta 33.4\left(\mathrm{~m}, \mathrm{CH}_{3} \mathrm{NP}\right), 122.4$ (br s, $\mathrm{C}_{0}^{2}$, $\left.\mathrm{C}_{1}^{2}, \mathrm{C}_{2}^{2}, \mathrm{C}_{3}^{2}\right), 129.4\left(\mathrm{~s}, \mathrm{C}_{0}^{3}, \mathrm{C}_{1}^{3}, \mathrm{C}_{2}^{3}\right), 129.9\left(\mathrm{~s}, \mathrm{C}_{3}^{3}\right), 131.5(\mathrm{~m}$, $\left.\mathrm{C}_{0}^{4}, \mathrm{C}_{1}^{4}, \mathrm{C}_{2}^{4}, \mathrm{C}_{3}^{4}\right), 140.9(\mathrm{~m}, \mathrm{CH}=\mathrm{NNP}), 148.5$ (br s, $\left.\mathrm{CH}=\mathrm{N}\right)$, $152.7\left(\mathrm{~m}, \mathrm{C}_{0}^{1}, \mathrm{C}_{1}^{1}, \mathrm{C}_{2}^{1}, \mathrm{C}_{3}^{1}\right), 157.0$ (br s, $\mathrm{CH}=\mathrm{N}$ ). Calcd for $\mathrm{C}_{720} \mathrm{H}_{816} \mathrm{Cl}_{48} \mathrm{~N}_{279} \mathrm{O}_{90} \mathrm{P}_{45} \mathrm{~S}_{42}$ (19260): C, 44.90; H, 4.27; N, 20.29. Found: C, 47.06; H, 4.33; N, 20.25.

\subsection{General procedure for the synthesis of dendrimers $2 \mathrm{e}-\mathrm{G}_{\mathbf{x}}(x=2,3)$}

To a solution of $200 \mathrm{mg}$ of $\mathbf{2 c}-\mathbf{G}_{\mathbf{x}}$ dendrimer $(\mathbf{x}=2$, $29.2 \mu \mathrm{mol} ; \mathbf{x}=3,13.5 \mu \mathrm{mol})$ in distilled THF was added 2-hydrazinopyridine $(\mathbf{x}=2,77.0 \mathrm{mg}, 702 \mu \mathrm{mol} ; \mathbf{x}=3$, $72.0 \mathrm{mg}, 648 \mu \mathrm{mol})$. The mixture was stirred at $40^{\circ} \mathrm{C}$ for $48 \mathrm{~h}$, then concentrated and precipitated with pentane $(20 \mathrm{~mL})$ and filtered. The resulting solid was washed by ether $(3 \times 20 \mathrm{~mL})$ and dried, leading to a pale yellow powder $(\mathbf{x}=2,250 \mathrm{mg} ; \mathbf{x}=3,241 \mathrm{mg})$.

4.6.1. Second generation $2 \mathbf{e}-\mathbf{G}_{\mathbf{2}} \cdot 95 \%$ Yield; ${ }^{31} \mathrm{P}\left\{{ }^{1} \mathrm{H}\right\} \mathrm{NMR}$ $\left(\mathrm{THF}_{\mathrm{d}}\right) \delta 8.5\left(\mathrm{~s}, \mathrm{P}_{0}\right), 62.5\left(\mathrm{~s}, \mathrm{P}_{2}\right), 62.9\left(\mathrm{~s}, \mathrm{P}_{1}\right) ;{ }^{1} \mathrm{H}$ NMR $\left(\mathrm{THF}_{\mathrm{d}}\right) \delta 3.33\left(\mathrm{~d},{ }^{3} \mathrm{~J}_{\mathrm{HP}}=13.8 \mathrm{~Hz}, 18 \mathrm{H}, \mathrm{CH}_{3} \mathrm{NP}_{1}\right), 3.35(\mathrm{~d}$, ${ }^{3} J_{\mathrm{HP}}=11.4 \mathrm{~Hz}, 36 \mathrm{H}, \mathrm{CH}_{3} \mathrm{NP}_{2}$ ), 6.66 ('t', ${ }^{3} J_{\mathrm{HH}}=5.7 \mathrm{~Hz}$, $24 \mathrm{H}, \mathrm{Pyr}), 7.05\left(\mathrm{~d},{ }^{3} J_{\mathrm{HH}}=6.5 \mathrm{~Hz}, 12 \mathrm{H}, \mathrm{C}_{0}^{2} \mathrm{H}\right), 7.25(\mathrm{~m}, 96 \mathrm{H}$, $\left.\mathrm{C}_{1}^{2} \mathrm{H}, \mathrm{C}_{2}^{2} \mathrm{H}, \mathrm{Pyr}\right), 7.52(\mathrm{~m}, 24 \mathrm{H}, \mathrm{Pyr}), 7.6-7.8(\mathrm{~m}, 102 \mathrm{H}$, 
$\left.\mathrm{C}_{0}^{3} \mathrm{H}, \mathrm{C}_{1}^{3} \mathrm{H}, \mathrm{C}_{2}^{3} \mathrm{H}, \mathrm{CH}=\mathrm{NNP}\right), 7.96(\mathrm{~s}, 24 \mathrm{H}, \mathrm{CH}=\mathrm{NNH})$, 8.04 (m, 24H, Pyr), 10.64 (s, 24H, NH); ${ }^{13} \mathrm{C}\left\{{ }^{1} \mathrm{H}\right\}$ NMR $\left(\right.$ THF-d $\left.\mathrm{d}_{8}\right) \delta 32.19\left(\mathrm{~d},{ }^{2} J_{\mathrm{CP}}=12 \mathrm{~Hz}, \mathrm{CH}_{3} \mathrm{NP}_{1}\right), 32.24(\mathrm{~d}$, ${ }^{2} J_{\mathrm{CP}}=12.1 \mathrm{~Hz}, \mathrm{CH}_{3} \mathrm{NP}_{2}$ ), 106.0 (s, Pyr), 114.6 (s, Pyr), 120.6 (br s, $\left.\mathrm{C}_{0}^{2}\right), 121.0\left(\mathrm{br} \mathrm{s}, \mathrm{C}_{1}^{2}, \mathrm{C}_{2}^{2}\right), 126.8\left(\mathrm{~s}, \mathrm{C}_{2}^{3}\right), 127.9$ (s, $\left.\mathrm{C}_{0}^{3}, \mathrm{C}_{1}^{3}\right), 132.08\left(\mathrm{~s}, \mathrm{C}_{0}^{4}\right), 132.1\left(\mathrm{~s}, \mathrm{C}_{1}^{4}\right), 132.8\left(\mathrm{~s}, \mathrm{C}_{2}^{4}\right), 137.2$ and $137.3(2 \mathrm{~s}$, Pyr and $\mathrm{CH}=\mathrm{NNPyr}), 140.0(\mathrm{~m}, \mathrm{CH}=\mathrm{NNP})$, 147.3 (s, Pyr), $150.05\left(\mathrm{~d},{ }^{2} J_{\mathrm{CP}}=8 \mathrm{~Hz}, \mathrm{C}_{2}^{1}\right), 150.6$ (d, $\left.{ }^{2} J_{\mathrm{CP}}=8 \mathrm{~Hz}, \mathrm{C}_{0}^{1}\right), 150.8\left(\mathrm{~d},{ }^{2} J_{\mathrm{CP}}=8 \mathrm{~Hz}, \mathrm{C}_{1}^{1}\right), 156.9$ (s, Pyr). Calcd for $\mathrm{C}_{432} \mathrm{H}_{384} \mathrm{~N}_{111} \mathrm{O}_{42} \mathrm{P}_{21} \mathrm{~S}_{18}$ (9030): C, 57.46; H, 4.29; N, 17.22. Found: C, 57.53; H, 4.35; N, 17.09.

4.6.2. Third generation $2 \mathbf{e}^{-G_{3}}$. $93 \%$ Yield; ${ }^{31} \mathrm{P}\left\{{ }^{1} \mathrm{H}\right\}$ NMR $\left(\right.$ THF-d $\left.\mathrm{d}_{8}\right) \delta 9.4$ (s, $\mathrm{P}_{\mathrm{H}}$ ), 63.6 (br s, $\mathrm{P}_{1}, \mathrm{P}_{2}, \mathrm{P}_{3}$ ); ${ }^{1} \mathrm{H}$ NMR (THF$\left.\mathrm{d}_{8}\right) \delta 3.32\left(\mathrm{~m}, 126 \mathrm{H}, \mathrm{CH}_{3} \mathrm{NP}_{1-3}\right), 6.64(\mathrm{~m}, 48 \mathrm{H}, \mathrm{Pyr}), 7.1(\mathrm{br}$ $\left.\mathrm{s}, 12 \mathrm{H}, \mathrm{C}_{0}^{2} \mathrm{H}\right), 7.25\left(\mathrm{~m}, 228 \mathrm{H}, \mathrm{C}_{1}^{2} \mathrm{H}, \mathrm{C}_{2}^{2} \mathrm{H}, \mathrm{C}_{3}^{2} \mathrm{H}, \mathrm{Pyr}\right), 7.49(\mathrm{~m}$, $48 \mathrm{H}, \mathrm{Pyr}), 7.55-7.85\left(\mathrm{~m}, 270 \mathrm{H}, \mathrm{C}_{0}^{3} \mathrm{H}, \mathrm{C}_{1}^{3} \mathrm{H}, \mathrm{C}_{2}^{3} \mathrm{H}, \mathrm{C}_{3}^{3} \mathrm{H}\right.$, $\mathrm{CH}=\mathrm{N}), 8.04(\mathrm{br} \mathrm{s}, 48 \mathrm{H}, \mathrm{Pyr}), 10.01(\mathrm{~s}, 48 \mathrm{H}, \mathrm{NH}) ;{ }^{13} \mathrm{C}\left\{{ }^{1} \mathrm{H}\right\}$ NMR (THF-d $\left.\mathrm{d}_{8}\right) \delta 32.8\left(\mathrm{~m}, \mathrm{CH}_{3} \mathrm{NP}\right), 107.0$ (s, Pyr), 115.2 (s, Pyr), 121.6 (br s, $\mathrm{C}_{0}^{2}$ ), 121.9 (br s, $\left.\mathrm{C}_{1}^{2}, \mathrm{C}_{2}^{2}, \mathrm{C}_{3}^{2}\right), 127.5$ (s, $\left.\mathrm{C}_{3}^{3}\right)$, $128.5\left(\mathrm{~s}, \mathrm{C}_{0}^{3}, \mathrm{C}_{1}^{3}, \mathrm{C}_{2}^{3}\right), 133.0\left(\mathrm{~s}, \mathrm{C}_{0}^{4}, \mathrm{C}_{1}^{4}, \mathrm{C}_{2}^{4}\right), 133.5\left(\mathrm{~s}, \mathrm{C}_{3}^{4}\right)$, 137.8 (br s, $\mathrm{Pyr}, \mathrm{CH}=\mathrm{NNPyr}), 139.9(\mathrm{~m}, \mathrm{CH}=\mathrm{NNP}), 147.9$ (s, Pyr), $151.1\left(\mathrm{~d},{ }^{2} J_{\mathrm{CP}}=8 \mathrm{~Hz}, \mathrm{C}_{3}^{1}\right), 151.8\left(\mathrm{~m}, \mathrm{C}_{0}^{1}, \mathrm{C}_{1}^{1}, \mathrm{C}_{2}^{1}\right)$, 157.7 (s, Pyr). Calcd for $\mathrm{C}_{912} \mathrm{H}_{816} \mathrm{~N}_{231} \mathrm{O}_{90} \mathrm{P}_{45} \mathrm{~S}_{42}(19192)$ : C, 57.08; H, 4.28; N, 16.86. Found: C, 57.21; H, 4.34; N, 16.78 .

\subsection{Synthesis and characterization of dendrimer $2 \mathrm{f}-\mathrm{G}_{3}$}

To a solution containing $112 \mathrm{mg}(5.8 \mu \mathrm{mol})$ of dendrimer $\mathbf{2 e}-\mathbf{G}_{\mathbf{3}}$ in $2 \mathrm{~mL}$ of THF was added dropwise at $0^{\circ} \mathrm{C}, 2.80 \mathrm{~mL}$ of aqueous $\mathrm{HCl} 0.1 \mathrm{M}$. The mixture was stirred for one hour at $0^{\circ} \mathrm{C}$, then concentrated and precipitated by addition of chloroform. After filtration, the resulting solid was washed with chloroform and ether and dried, leading to $117 \mathrm{mg}$ of 2f-G $\mathbf{G}_{3}$ obtained as a pale yellow powder. 93\% yield; ${ }^{31} \mathrm{P}\left\{{ }^{1} \mathrm{H}\right\}$ NMR (DMSO-d $\left.\mathrm{d}_{6}\right) \delta 11.6\left(\mathrm{~s}, \mathrm{P}_{0}\right), 65.3\left(\mathrm{~s}, \mathrm{P}_{3}\right)$, $65.8\left(\mathrm{br} \mathrm{s}, \mathrm{P}_{1}, \mathrm{P}_{2}\right) ;{ }^{1} \mathrm{H}$ NMR (DMSO-d $\left.\mathrm{d}_{6}\right) \delta 3.31(\mathrm{~m}, 126 \mathrm{H}$, $\mathrm{CH}_{3} \mathrm{NP}_{1-3}$ ), 6.96 (m, 48H, Pyr), 7.2 (br m, $240 \mathrm{H}, \mathrm{C}_{0}^{2} \mathrm{H}, \mathrm{C}_{1}^{2} \mathrm{H}$, $\mathrm{C}_{2}^{2} \mathrm{H}, \mathrm{C}_{3}^{2} \mathrm{H}, \mathrm{Pyr}$ ), 7.69 (m, 48H, Pyr), 7.96 (br m, 270H, $\mathrm{C}_{0}^{3} \mathrm{H}$, $\left.\mathrm{C}_{1}^{3} \mathrm{H}, \mathrm{C}_{2}^{3} \mathrm{H}, \mathrm{C}_{3}^{3} \mathrm{H}, \mathrm{CH}=\mathrm{N}\right), 8.32(\mathrm{~m}, 48 \mathrm{H}, \mathrm{Pyr}) ;{ }^{13} \mathrm{C}\left\{{ }^{1} \mathrm{H}\right\}$ NMR (DMSO-d $\left.\mathrm{d}_{6}\right) \delta 34.0\left(\mathrm{~m}, \mathrm{CH}_{3} \mathrm{NP}\right), 112.7$ (s, Pyr), 115.4 (s, Pyr), 122.1 (br s, $\mathrm{C}_{0}^{2}, \mathrm{C}_{1}^{2}, \mathrm{C}_{2}^{2}, \mathrm{C}_{3}^{2}$ ), 129.3 (br s, $\mathrm{C}_{0}^{3}, \mathrm{C}_{1}^{3}, \mathrm{C}_{2}^{3}$ ), $130.3\left(\mathrm{~s}, \mathrm{C}_{2}^{3}\right) 131.8\left(\mathrm{~s}, \mathrm{C}_{3}^{4}\right), 132.9\left(\mathrm{~s}, \mathrm{C}_{0}^{4}, \mathrm{C}_{1}^{4}, \mathrm{C}_{2}^{4}\right), 137.9(\mathrm{~s}$, Pyr), $141.6($ br s, $\mathrm{CH}=\mathrm{NNPyr}), 144,9(\mathrm{~m}, \mathrm{CH}=\mathrm{NNP})$, 147.1 (s, Pyr), 150.2 (br s, $\mathrm{C}_{3}^{1}$ ), 151.6 (s, $\left.\mathrm{C}_{2}^{1}\right), 152.3$ (br s, $\mathrm{C}_{1}^{1}$, $\mathrm{C}_{0}^{1}$ ). Calcd for $\mathrm{C}_{912} \mathrm{H}_{864} \mathrm{Cl}_{48} \mathrm{~N}_{231} \mathrm{O}_{90} \mathrm{P}_{45} \mathrm{~S}_{42}$ (20943): C, $52.31 ; \mathrm{H}, 4.16 ; \mathrm{N}, 15.45$. Found: C, 52.25; H, 4.08; N, 15.37.

\section{References}

1. For some pioneering references in this field, see: (a) Buhleier, E.; Wehner, W.; Vögtle, F. Synthesis 1978, 155. (b) Tomalia, D. A.; Baker, H.; Dewald, J.; Hall, M.; Kallos, G.; Martin, S.; Roeck, J.; Ryder, J.; Smith, P. Polym. J. 1985, 17, 117. (c) Newkome, G. R.; Yao, Z. Q.; Baker, G. R.; Gupta, V. K. J. Org. Chem. 1985, 50, 2003. (d) Hawker, C. J.; Fréchet, J. M. J. J. Am. Chem. Soc. 1990, 112, 7638. (e) Miller, T. M.; Neenan, T. X. Chem. Mater. 1990, 2, 346.

2. For some very recent reviews concerning dendrimers, see: (a) Newkome, G. R.; Vögtle, F.; Moorefield, C. N. Dendrimers and Dendrons; Wiley: New York, 2001. (b) Fréchet, J. M. J.; Tomalia, D. A. Dendrimers and other Dendritic Polymers; Wiley: New York, 2001. (c) Tully, D. C.; Fréchet, J. M. J. Chem. Commun. 2001, 1229. (d) Grayson, S. M.; Fréchet, J. M. J. Chem. Rev. 2001, 101, 3819. (e) Majoral, J. P.; Caminade, A. M.; Maraval, V. Chem. Commun. 2002, 2929.

3. (a) Balogh, L.; de Leuze-Jallouli, A.; Dvornic, P.; Kunugi, Y.; Blumstein, A.; Tomalia, D. A. Macromolecules 1999, 32, 1036. (b) Dvornic, P. R.; Tomalia, D. A. Starburst Dendrimers, Technology Review; Dendritech, Inc: Midland MI, 1995.

4. Omotowa, B. A.; Keefer, K. D.; Kirchmeier, R. L.; Shreeve, J. M. J. Am. Chem. Soc. 1999, 121, 11130.

5. Miller, T. M.; Neenan, T. X.; Zayas, R.; Bair, H. E. J. Am. Chem. Soc. 1992, 114, 1018.

6. Launay, N.; Caminade, A. M.; Lahana, R.; Majoral, J. P. Angew. Chem., Int. Ed. Engl. 1994, 33, 1589.

7. (a) Launay, N.; Caminade, A. M.; Majoral, J. P. J. Am. Chem. Soc. 1995, 117, 3282. (b) Slany, M.; Bardaji, M.; Casanove, M. J.; Caminade, A. M.; Majoral, J. P.; Chaudret, B. J. Am. Chem. Soc. 1995, 117, 9764. (c) Launay, N.; Slany, M.; Caminade, A. M.; Majoral, J. P. J. Org. Chem. 1996, 61, 3799. (d) Lartigue, M. L.; Slany, M.; Caminade, A. M.; Majoral, J. P. Chem. Eur. J. 1996, 2, 1417. (e) Slany, M.; Caminade, A. M.; Majoral, J. P. Tetrahedron Lett. 1996, 37, 9053. (f) Bardaji, M.; Kustos, M.; Caminade, A. M.; Majoral, J. P.; Chaudret, B. Organometallics 1997, 16, 403. (g) Slany, M.; Bardaji, M.; Caminade, A. M.; Chaudret, B.; Majoral, J. P. Inorg. Chem. 1997, 36, 1939. (h) Bardaji, M.; Caminade, A. M.; Majoral, J. P.; Chaudret, B. Organometallics 1997, 16, 3489. (i) Prévôté, D.; Caminade, A. M.; Majoral, J. P. J. Org. Chem. 1997, 62, 4834. (j) Lartigue, M. L.; Caminade, A. M.; Majoral, J. P. Tetrahedron: Asymmetry 1997, 8, 2697. (k) Prévôté, D.; Le Roy-Gourvenec, S.; Caminade, A. M.; Masson, S.; Majoral, J. P. Synthesis 1997, 1199. (1) Prévôté, D.; Donnadieu, B.; Moreno-Manas, M.; Caminade, A. M.; Majoral, J. P. Eur. J. Org. Chem. 1999, 1701. (m) Sebastian, R. M.; Caminade, A. M.; Majoral, J. P.; Levillain, E.; Huchet, L.; Roncali, J. Chem. Commun. 2000, 507. (n) Maraval, V.; Laurent, R.; Caminade, A. M.; Majoral, J. P. Organometallics 2000, 19, 4025. (o) Schmid, G.; Meyer-Zaika, W.; Pugin, R.; Sawitowski, T.; Majoral, J. P.; Caminade, A. M.; Turrin, C. O. Chem. Eur. J. 2000, 6, 1693. (p) Le Derf, F.; Levillain, E.; Gorgues, A.; Sallé, M.; Sebastian, R. M.; Majoral, J. P. Angew. Chem. Int. Ed. 2001, 40, 224. (q) Turrin, C. O.; Chiffre, J.; Daran, J. C.; de Montauzon, D.; Caminade, A. M.; Manoury, E.; Balavoine, G.; Majoral, J. P. Tetrahedron 2001, 57, 2521. (r) Göller, R.; Vors, J. P.; Caminade, A. M.; Majoral, J. P. Tetrahedron Lett. 2001, 42, 3587.

8. (a) Launay, N.; Caminade, A. M.; Majoral, J. P. J. Organomet. Chem. 1997, 529, 51. (b) Maraval, V.; Prévôté-Pinet, D.; Laurent, R.; Caminade, A. M.; Majoral, J. P. New J. Chem. 2000, 24, 561. (c) Maraval, V.; Laurent, R.; Donnadieu, B.; Mauzac, M.; Caminade, A. M.; Majoral, J. P. J. Am. Chem. Soc. 2000, 122, 2499. (d) Maraval, V.; Laurent, R.; Merino, S.; Caminade, A. M.; Majoral, J. P. Eur. J. Org. Chem. 2000, 3555 .

9. (a) Lartigue, M. L.; Launay, N.; Donnadieu, B.; Caminade, A. M.; Majoral, J. P. Bull. Soc. Chim. Fr. 1997, 134, 981. (b) Lartigue, M. L.; Caminade, A. M.; Majoral, J. P. Phosphorus, Sulfur Silicon 1997, 123, 21.

10. (a) Galliot, C.; Prévoté, D.; Caminade, A. M.; Majoral, J. P. J. Am. Chem. Soc. 1995, 117, 5470. (b) Huc, V.; Balueva, A.; Sebastian, R. M.; Caminade, A. M.; Majoral, J. P. Synthesis 
2000, 726. (c) Turrin, C. O.; Chiffre, J.; de Montauzon, D.; Daran, J. C.; Caminade, A. M.; Manoury, E.; Balavoine, G.; Majoral, J. P. Macromolecules 2000, 33, 7328. (d) Sebastian, R. M.; Magro, G.; Caminade, A. M.; Majoral, J. P. Tetrahedron 2000, 56, 6269. (e) Brauge, L.; Magro, G.; Caminade, A. M.; Majoral, J. P. J. Am. Chem. Soc. 2001, 123, 6698. Erratum: Brauge, L.; Magro, G.; Caminade, A. M.; Majoral, J. P. J. Am. Chem. Soc., 2001, 123, 8446. (f) Merino, S.; Brauge, L.; Caminade, A. M.; Majoral, J. P.; Taton, D.; Gnanou, Y. Chem. Eur. J. 2001, 7, 3095. (g) Turrin, C. O.; Chiffre, J.; de Montauzon, D.; Balavoine, G.; Manoury, E.; Caminade, A. M.; Majoral, J. P. Organometallics 2002, 21, 1891. (h) Sebastian, R. M.; Blais, J. C.; Caminade, A. M.; Majoral, J. P. Chem. Eur. J. 2002, 8, 2172.

11. (a) Galliot, C.; Larré, C.; Caminade, A. M.; Majoral, J. P. Science 1997, 277, 1981. (b) Larré, C.; Caminade, A. M.; Majoral, J. P. Angew. Chem. Int. Ed. Engl. 1997, 36, 596. (c) Larré, C.; Donnadieu, B.; Caminade, A. M.; Majoral, J. P. J. Am. Chem. Soc. 1998, 120, 4029. (d) Larré, C.; Donnadieu, B.; Caminade, A. M.; Majoral, J. P. Chem. Eur. J. 1998, 4, 2031. (e) Larré, C.; Bressolles, D.; Turrin, C.; Donnadieu, B.; Caminade, A. M.; Majoral, J. P. J. Am. Chem. Soc. 1998, 120, 13070. (f) Cadierno, V.; Igau, A.; Donnadieu, B.; Caminade, A. M.; Majoral, J. P. Organometallics 1999, 18, 1580. (g) Majoral, J. P.; Larré, C.; Laurent, R.; Caminade, A. M. Coord. Chem. Rev. 1999, 190-192, 3. (h) Brauge, L.; Caminade, A. M.; Majoral, J. P.; Slomkowski, S.; Wolszczak, M. Macromolecules 2001, 34, 5599.

12. (a) Majoral, J. P.; Caminade, A. M. Top. Cur. Chem. 1998, 197, 79. (b) Caminade, A. M.; Laurent, R.; Chaudret, B.;
Majoral, J. P. Coord. Chem. Rev. 1998, 178-180, 793. (c) Majoral, J. P.; Caminade, A. M. Chem. Rev. 1999, 99, 845. (d) Caminade, A. M.; Maraval, V.; Laurent, R.; Majoral, J. P. Curr. Org. Chem. 2002, 6, 739.

13. Lartigue, M. L.; Donnadieu, B.; Galliot, C.; Caminade, A. M.; Majoral, J. P.; Fayet, J. P. Macromolecules 1997, 30, 7335.

14. Marmillon, C.; Gauffre, F.; Gulik-Krzywicki, T.; Loup, C.; Caminade, A. M.; Majoral, J. P.; Vors, J. P.; Rump, E. Angew. Chem. Int. Ed. 2001, 40, 2626.

15. Blanzat, M.; Turrin, C. O.; Perez, E.; Rico-Lattes, I.; Caminade, A. M.; Majoral, J. P. Chem. Commun. 2002, 1864.

16. (a) Allcock, H. R. Phosphorus-Nitrogen Compounds; Academic: New York, 1972. (b) Neilson, R. H.; WisianNeilson, P. Chem. Rev. 1988, 88, 541.

17. Blais, J. C.; Turrin, C. O.; Caminade, A. M.; Majoral, J. P. Anal. Chem. 2000, 72, 5097.

18. Loup, C.; Zanta, M. A.; Caminade, A. M.; Majoral, J. P.; Meunier, B. Chem. Eur. J. 1999, 5, 3644.

19. Boggiano, M. K.; Soler-Illia, G. J. A. A.; Rozes, L.; Sanchez, C.; Turrin, C. O.; Caminade, A. M.; Majoral, J. P. Angew. Chem. Int. Ed. 2000, 39, 4249.

20. Mathivet, T.; Monflier, E.; Castanet, Y.; Mortreux, A.; Couturier, J. L. Tetrahedron Lett. 1998, 39, 9411.

21. (a) Dantras, E.; Lacabanne, C.; Caminade, A. M.; Majoral, J. P. Macromolecules 2001, 34, 3808. (b) Dantras, E.; Caminade, A. M.; Majoral, J. P.; Lacabanne, C. J. Phys. D: Appl. Phys. 2002, 35, 5. (c) Dantras, E.; Dandurand, J.; Lacabanne, C.; Caminade, A. M.; Majoral, J. P. Macromolecules 2002, 35, 2090. 